\title{
Are The Cop21 Objectives Implementable?
}

\author{
Jan-Erik Lane \\ Public Policy Institute, Belgrade, Republika Srbija \\ E-mail: janeklane@gmail.com
}

Received: May 12, 2016 Accepted: May 31, 2016 Published: June 6, 2016

doi:10.5296/bmh.v4i1.9563～URL: http://dx.doi.org/10.5296/bmh.v4i1.9563

\begin{abstract}
Policy implementation is often difficult to achieve, especially in a heavily decentralised structure, policy analysts like Wildavsky \& Sabatier suggested. Now, the international community is going to guide a large number of governments or states towards the accomplishment of the COP21 objectives, although no governance mechanisms have yet been set up or identified. The implementation process for the COP21 Agreement must now start in order to have any chance of succeeding with its main objective of a $40 \%$ reduction in CO2 emissions until 2030. Actually, this process of implementation is expected to go on for the entire century, as COP21 promises a carbon free economy sometime after 2050. I argue that it is likely that many governments will only deliver small changes in emission decreases, but keep enough fossil fuel energy sources in order to maintain some positive rate of economic growth. Complete decarbonisation of entire societies is a figment of Sachs' imagination concerning "sustainable development". Thee management tasks in relation to the fulfilment of the COP21 goals are mindboggling.
\end{abstract}

Kewwords: COP21 process, Implementation theory, Management, Reneging, Decarbonisation, Energy-environment conundrum, GHG:s and CO2:s, Sachs, Wildavsky, Sabatier, Williamson, Collective action, International governance 
1. Introduction

As the COP21 Agreement comes closer to being a valid treaty under public international law, the implementation process has to begin, as time is pressing, for two reasons. On the one hand, the COP21 outlines a rapid halt and reduction in CO2 emissions, which requires action from state and society in the signing countries. On the other hand, the evidence about global warming is mounting, all indicating that this process is moving ahead at alarming speed (https://www.co2.earth/).

\subsection{Desirability}

Most scholars have now come to support the hypothesis of anthropogenic climate change. Few support the so-called cornucopian stand-point that global warming is a figment of the imagination of green fanatics attempting to hurt global capitalism (Simon, 2003; Wildavsky, 1997; Lomborg, 2007). One fully understands the enthusiasm after the making of the COP21 Agreement, when $A L L$ governments signed, after years of discussions and deliberations. What is at stake in COP21 is a heavily decentralized process of implementation, where each national government of the signing states will chose its policy mix in order to accomplish the main objectives with COP21. It is said that there will be some form of international governance of the implementation, including periodic reviews of country results and money support from a superfund. Yet, the implementation of the halting and decrease of CO2:s is basically decentralized to each country, with perhaps 5-year overviews, but little in terms of control and sanctions for reneging.

Given the importance of the COP21, upon which the future of mankind may hinge, each state now has incentives to start elaborate a mix of policies that promote the chief COP21 objectives:

- $\quad$ Reversing the trend in CO2:s and also GHG:s from 2018-2020;

- $\quad$ Decreasing the CO2:s by $40 \%$ until 2030;

- $\quad$ Eliminating the CO2:s completely until the end of the century.

This must be the most encompassing and longest implementation process in the history of policy analysis. Is total decarbonisation of the economies of the world achievable, given the GDP-energy-emissions links to be enquired into below? I am truly sceptical, but the desirability of halting global warming and the fossil fuel dependency of most countries are no longer in doubt, as cornucopianism (Earth = horn of plenty) is rejected by most experts.

\subsection{Feasibility}

One may speak of various kinds of feasibility in relation to decarbonisation, meaning elimination of fossil fuels, especially coal, as sources of energy in society. Principally, we have to distinguish between:

- Technological feasibility;

- Economic feasibility. 
The COP21 framework may satisfy the first form of feasibility, as new technologies are forthcoming almost everywhere: solar panels, wind mills and diesel engines - all cheaper and more efficient or performing. Carbon capture and carbon sucking appear possible, and nuclear power stations may be built with no melt down risks. Yet, economic feasibility is highly questionable, as large scale decarbonisation will be extremely expensive and may cause economic depressions. We look at the most vulnerable countries below, having an energy mix that is heavily reliant upon solids and the fossil fuels. People, or states, may simply prefer resilience, i.e., wait and see how dangerous global warming really turns out to be.

I emphasize the following points concerning the realistic odds of implementing COP 21 objectives:

a) Achieving these goals presents formidable tasks for governments, the business community and civil society - the most important policy commitment in this century besides maintaining global peace;

b) The mix of policies will be country specific and path dependent upon how much the country now relies upon fossil fuels and what other options for energy sources are available;

c) Decarbonisation at the $40 \%$ level is bound to have repercussions for economic growth. Perhaps economist J. Sachs is correct when he claims that decarbonisation must lead to a "sustainable economic life", even if economic output would have to fall, maybe as much as 20\% (Sachs, 2015).

Substantiating the points a) and b) with empirical evidence from various international agencies and their websites, I am very sceptical about the feasibility of a "sustainable economy" on the global level. It is more likely that global warming will run its dismal course, with Nature spelling out the dire consequences for mankind and its social systems of climate change. Some biologists even claim that the Cro Magnon species may extinguish itself by 2100 .

\section{Decarbonisation, Energy and the Cop21 Implementation}

Decarbonisation or the reduction of fossil fuels as energy sources is the policy objective favoured by the COP21 framework. However, the COP21 Agreement says little about the consequences for access to cheap energy and in turn the growth implications.

\subsection{Sachs}

Sachs has launched a coherent call for the world to move towards sustainable development, based on decarbonisation of the energy systems of countries (http://jeffsachs.org/2015/08/sustainable-development-for-humanitys-future/). He has correctly emphasized the close link between economic development or growth and the massive use of fossil fuels as energy sources during the last 20 years, resulting in the enormous expansion of GHG emissions (Figure 1). Ideally, a country would wish to start reducing its emissions of GHG:s without any major impact upon the GDP. This would require a policy mix of promoting energy efficiency, moving towards the use of renewables 


\section{Macrothink}

massively and cutting back upon fossil fuels. Sachs is well aware of the dilemma: decarbonisation versus rapid economic development for countries aiming at a catch-up strategy. His solution is the somewhat amorphous concept of a sustainable economy.

\section{World GDP Growth Divided Between Energy Growth and Efficiency/Technology Growth}

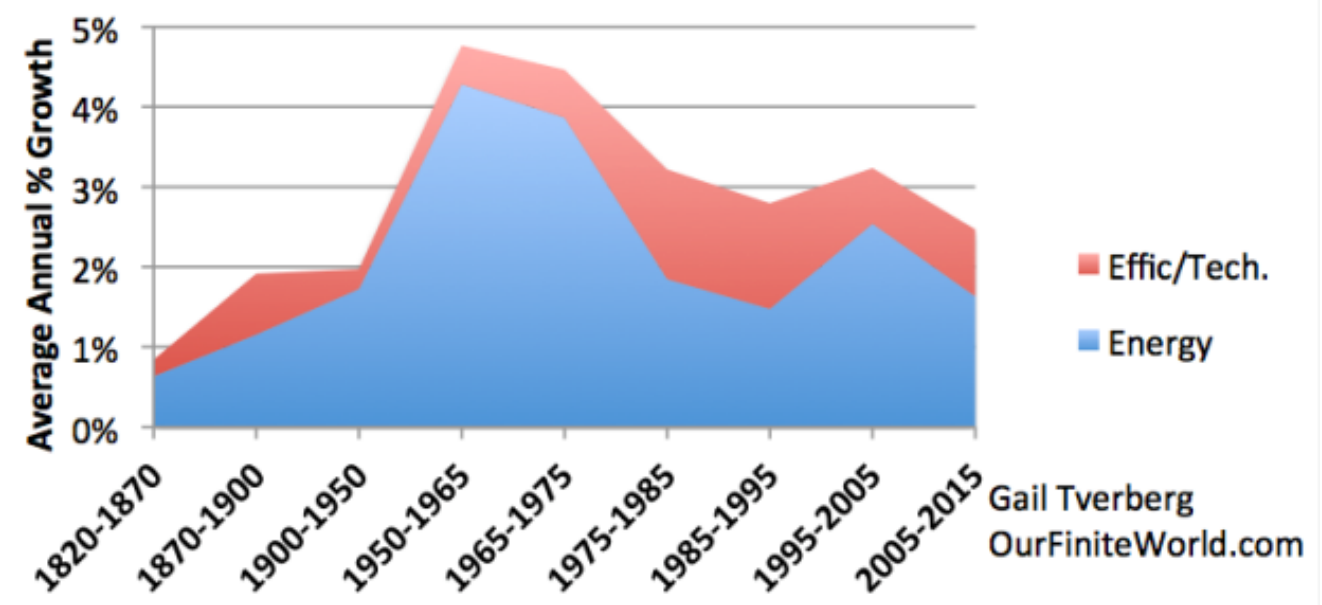

Figure 1. Energy and GDP growth

Source: http://www.zerohedge.com/news/2015-09-15/how-our-energy-problems-lead-debt-collapse-problem

The idea of a sustainable economy suffers from the same weakness as the notion of a planned economy. Who is to control the key parameters in a sustainable economy: markets or states?

\subsection{Wildavsky}

As maybe the most gifted American political scientist of the $20^{\text {th }}$ century emphasized in his manifold writings, Aaron Wildavsky, policy implementation involves much more than ordinary public administration or governance. The central distinction is that between output, i.e., decisions, legislation and budgeting, on the one hand and outcome, i.e., the real results occurring in the social systems at some point in time (Pressman \& Wildavsky, 1973). Redirecting political science and public administration towards policy analysis of outcomes, he was joined by scholars from other disciplines in new centres to study the actual effects of government decisions and actions, and not only its intensions or promises.

The empirical enquiries into a number of implementation processes with the national or local governments in a country revealed the occurrence of a number of surprising features, such as:

i) An often sharp distinction between intended and unintended outcomes;

ii) Unintended outcomes were often more dys-functional than eu-functional;

iii) Often important unrecognized outcomes were identified; 
iv) In an implementation process, the means and the goals could be confused-goal displacement;

v) Over time, implementation proved often to be dynamic, meaning that both means and goals were reinterpreted and replaced;

vi) The concept of rational policy-making as complete and efficient achievement of stated objectives had to be questioned and the inherent difficulties in policy implementation be recognized.

Wildavsky drew the sound conclusion that policy analysts face the task of informing government, bureaucracies and civil society as well as markets about the TRUTH concerning the probability of accomplishing objectives by clearly stated means (Wildavsky, 1979). He did not, it should be pointed out, exaggerate the implementation problems into a theory of irrational behaviour - the so-called carbage can model (March \& Olsen, 1976). But one must be aware of the problematic motivation with several players in an implementation process, which economist Williamson (1973) called “opportunistic behaviour with guile”. Sabatier (1988) argued that implementation may result in partial success, if managed by so-called “advocacy coalitions”, calling for policy networks including government, the bureaucracy, business community and civil society in order to improve information and augment motivation in policy implementation.

It is always underlined in teachings about international politics and public international law that enforcement is the weak link in the entire system of regulations by international organisations and treaty laws. Implementation of intra state agreements can often not be enforced, which opens up for many kinds of opportunistic behaviour: promise against compliance.

When we look at the different positions of a few states with regard to the implementation of COP21, we have to take into account both their emissions profile and the possibility of reneging. If, and I emphasize IF, a government is forced to choose between CO2:s reduction and economic development, it may be very tempted by reneging in some form or another. Anthropogenic emissions originate often with energy consumption, which is basic to the economy in a wide sense-industry, transportation, housing, construction, agriculture, etc.

In the news concerning global warming, one encounters lots of confusion about policy outputs and outcomes, like:

- New innovations within energy reducing or eliminating CO2:s, but these reductions may be overrules by increases elsewhere;

- CO2:s are said to be "stalling" in 2014-2015, but that does not stop climate change, as COP21 requires a massive $40 \%$ reduction;

- Some coal mines are closed in China, we hear, but perhaps they were small and inefficient? How many new and bigger ones are planed? And the expansion of the car market in China may overturn these events. 


\section{Macrothink}

One must $A D D U P$ the plus and the minus events all the time, and not only report on the positive news.

\subsection{Energy $=$ Capacity to do work}

The COP21 framework focuses upon CO2:s among the GHG:s, although methane may become very dangerous. In addition, the COP21 targets only certain sources of CO2:s, namely anthropogenic ones stemming from energy consumption in a wide sense. Energy is indispensable not only in the Cosmos of stars and planets, but also for all kinds of social systems of men and women. When analysing the greenhouse gases (GHG), one focuses upon the following energy sources and their emission impacts:

- Solids and fossil fuels—strong CO2 impact

- Modern biofuels - weak CO2 impact

- Nuclear power-no CO2 impact

- Hydro power - no CO2 impact

- Wind power-no CO2 impact

- Geo-thermal power-no CO2 impact.

The construction of power stations has in general a CO2 impact, when lots of cement is employed. However, these are the options that countries may pursue, depending upon their environment and capacity to import and export energy.

The emission consequences of these energy sources may be identified in a few global Figures, clarifying the actual global predicament concerning the real sources of $\mathrm{CO} 2$. What we want to know is how energy consumption results in emissions outcomes.

Figure 2 links anthropogenic CO2 emissions strongly with the burning of fossil fuels. The CO2:s constitute roughly $70 \%$ of all GHG:s, and they have been in constant increase since the latter half of the $20^{\text {th }}$ century. 


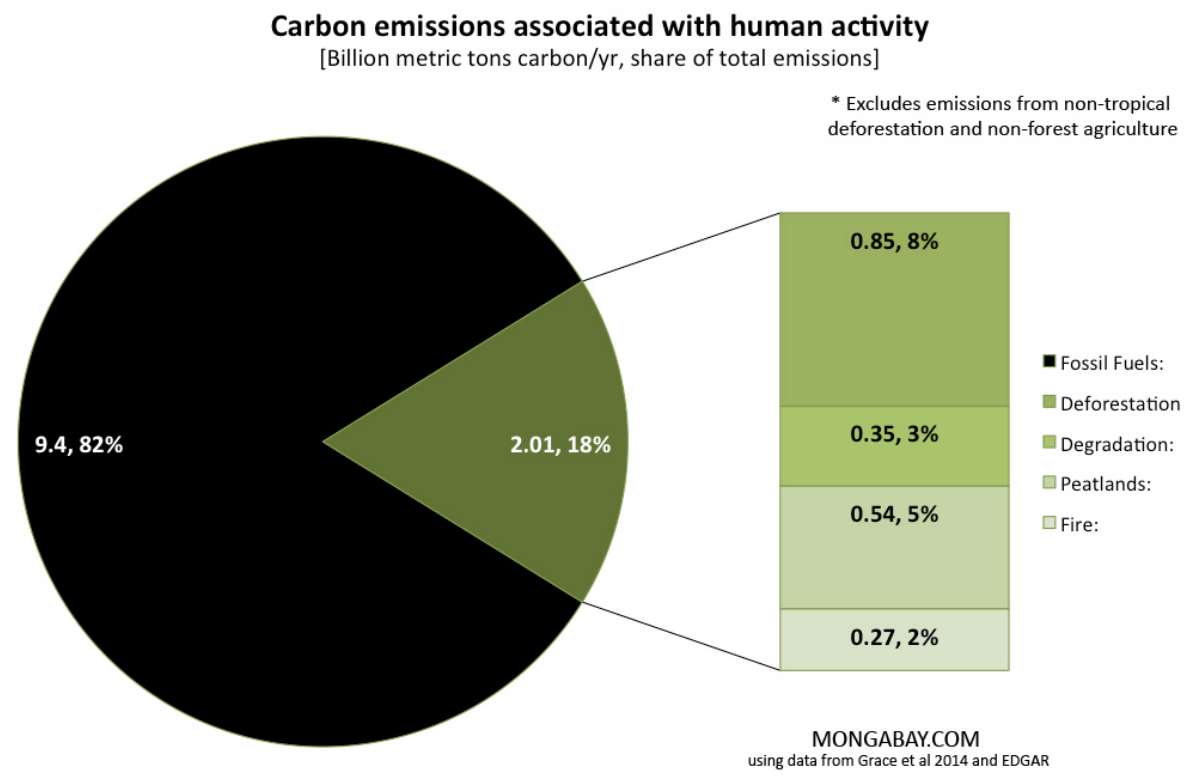

Figure 2. Global energy sources of CO2:s

Source: http://www.mywallpaper.top/time-lapse-history-of-human-global-co2-emissions-youtube.html

One could point out that also renewables can result in CO2:s, like the burning of wood or biomass, but people are quick to retort that bioenergy also consumes CO2:s, making them neutral carbon wise.

The relevance of fossil fuels to human societies appears from Figure 3. The fossil fuels combined make up the major part of energy sources for human activities, globally speaking, especially when one also includes the traditional renewables among the solids.

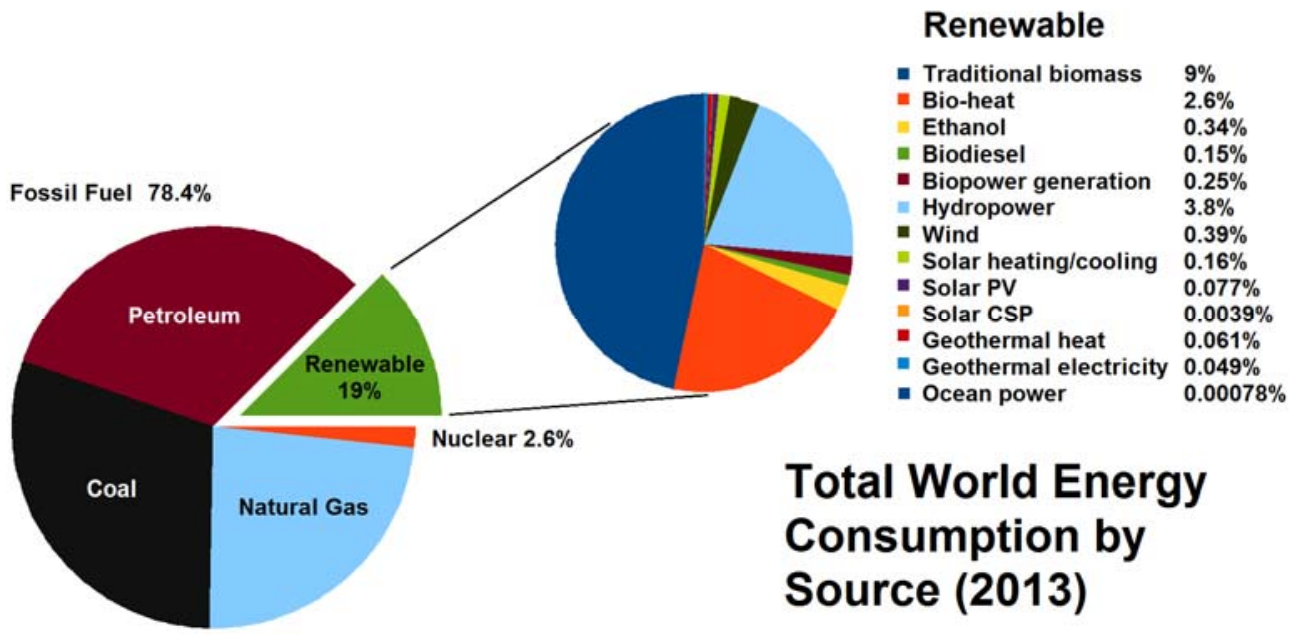

Figure 3. Energy sources globally

Source: http://archaeopteryxgr.blogspot.com/2015_08_01_archive.html 
Pursuing the COP21 agenda, the use of fossil fuels must be reduced. It can be done in two ways. Either one simply brings down the burning of coal, oil and natural gas, or one attempts to replace fossil fuels with nuclear power and renewables. If the goal is simply to decrease CO2:s with $40 \%$, in terms 1990 or 2016 consumption, then one could just close down lots of facilities, like e.g., old coal and oil fired stations and not replace them with natural gas stations.

However, there is a catch. And the crux of the matter is economic development or growth. Hitherto, energy consumption has been a major pillar for strong economic advances, especially in Asia. Does cutting the burning of fossil fuels reduce affluence and increase poverty? Remember that the UN has other goals than reducing CO2:s, such as its general developmental goals of economic growth and poverty reduction. Country wealth and affluence originates with work, and energy is basically the capacity to do work.

\section{Theory}

It seems reasonable to argue that the required $40 \%$ reduction of $\mathrm{CO} 2$ emissions from their 1990 base will prove extremely difficult to implement for most countries in the world, at least if it is to be done without cuts in economic output. Moreover, it also appears adequate to claim that countries that are heavily reliant upon fossil fuels today will face most difficulties. Thus, they may have incentive to renege one way or the other.

On the other hand, one would like to say that countries with an energy mix of both fossil fuels and renewables would have a better chance to succeed in implementing the COP21 goals, especially when they have large experience of hydro and nuclear power. Yet, countries differ much in their energy mixes, from Uruguay with almost no reliance upon fossil fuels to the Gulf States that rest almost entirely upon fossil fuels.

I will explore the variety of energy mixes in a small sample of various countries below. Energy consumption in a wide sense is typical of every sector of society and it has consequences for $\mathrm{CO} 2$ emissions. I will relate the country emissions to its GDP development and explore the different energy mixes. The analysis below focuses upon:

$<$ GDP-COP link, energy mix >

as a country facing the implementation of COP21 goals must know where it is on its GDP-CO2 curve as well as what energy sources it can count upon.

Every day we can see the coming of the major risk to social and ecological systems by looking at the amount of CO2:s in the Earth's atmosphere (Earth's Co2 Home Page). It now stands at ppm 408, a sharp rise in the last years. Concomitant is the slow but ineluctable rise in global average temperature, where the temperature rise may actually by larger in certain regions, like the polar areas and the oceans. As climate change could be highly detrimental to social and ecological systems on Planet Earth, the UN and governments of the countries of the world have finally counter-acted with: COP21 Agreement. The key question today is whether the COP21 process can be managed in such an effective manner that it halts and decreases this gigantic risk to mankind in particular and biological life in general. 


\section{Macrothink}

The core of the problematic is the access to energy, because energy is the capacity to do work. Without work, there can be no wealth of nations, argued Adam Smith; and without productive labour, there can be no wealth: Supply determines demand, as Say stated it. An implementation success of the COP21 process is doubtful, because energy is so important to social systems and does lead to GHG emissions.

\section{Empirical Findings}

\subsection{Asian Scene}

Several countries adhere to the label "emerging economies". Here, I look at China, India, Thailand and Malaysia as well as Iran.

\subsubsection{China}

One finds that the emissions of CO2:s follows economic development closely in many countries, like China, South Koreas and most Latin American countries. The basic explanation is population growth and GDP growth-more people breathing and searching for higher life style. Take the case of China, whose emissions are the largest in the world, totally speaking (Figure 4). Interestingly, China has begun a fundamental change of its energy policy in 2015, reacting to mostly domestic demands for cleaner air and environment.

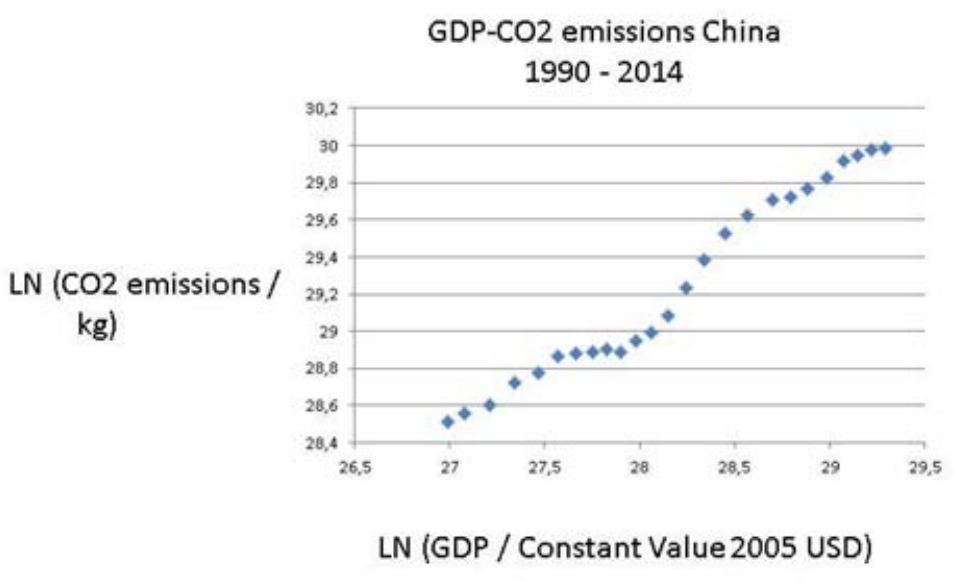

Figure 4. China: LN (CO2/ Kg and LN (GDP / Constant Value 2005 USD) (y = 0,7x; R² = $0,97)$

The sharp increase in CO2:s in China reflects not only the immensely rapid industrialization and urbanization of the last 30 years, but also its problematic energy mix (Figure 5), which is now up for overhaul. 


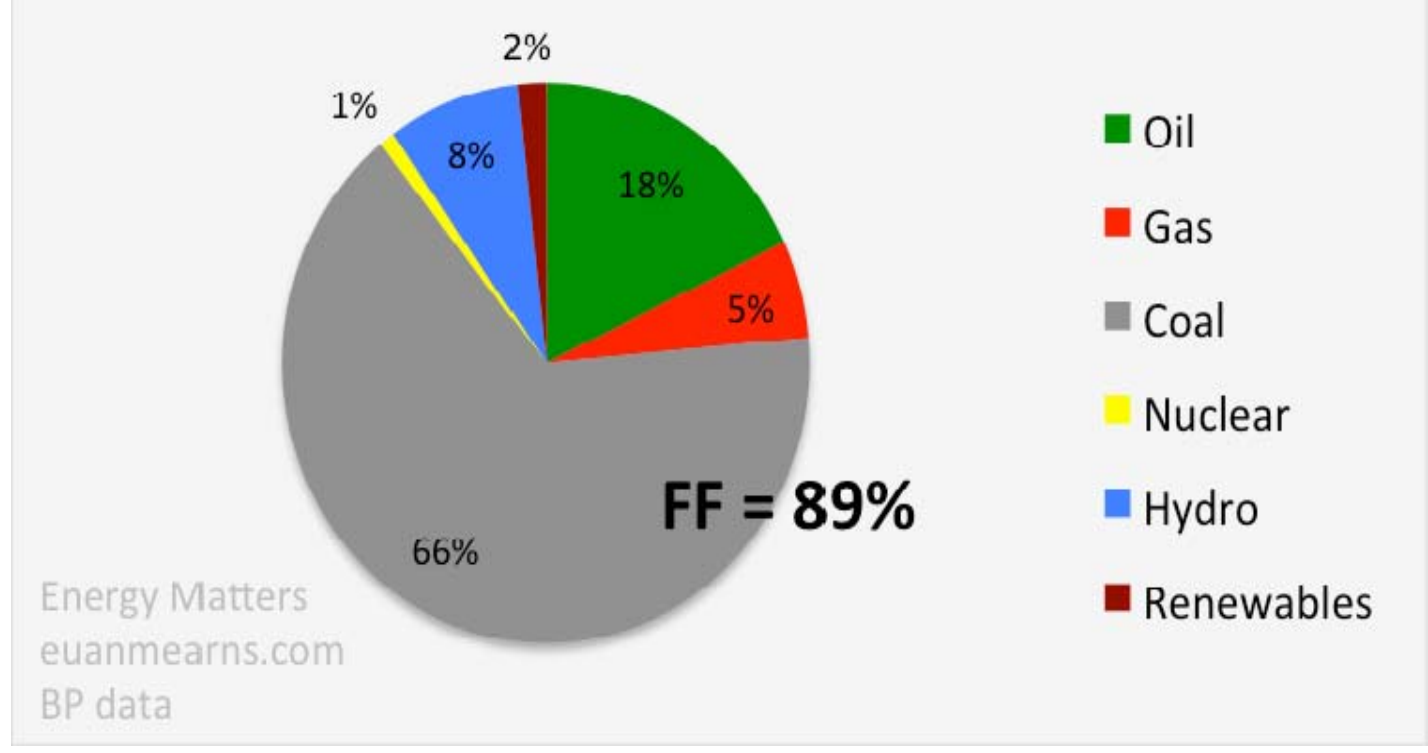

Figure 5. China energy consumption 2014

Source: http://euanmearns.com/china-post-industrial-revolution/

Almost 70 per cent of the energy consumption comes from the burning of coal with an additional 20 per cent from other fossil fuels. The role of nuclear and renewable energy sources with the exception of hydro power is very small indeed. This energy mix makes China very vulnerable to demands for radically cutting $\mathrm{CO} 2$ emissions: use other energy sources or massive installation of highly improved filters for carbon capture? It is true that China has turned to wind power, solar power and nuclear power massively recently, but the task of achieving a $40 \%$ reduction is enormous. China evidently hopes to respect its COP21 commitments while still enjoying an economic growth rate of above $5 \%$, but it is realistic? New coal plants have actually been opened recently, replacing out-dated old ones in order to propel growth.

It should be pointed out that several small countries have much higher emissions per capita than China. This raises the enormously difficult problematic of fair cuts of emissions. Should the largest polluters per capita like the rich Gulf States cut most or the biggest aggregate polluters, like emerging economies China, India and Indonesia for instance? At COP21 this issue about redistribution was resolved by the creation of a super fund to assist energy transition and environment protection in developing counties, as proposed early by economist Stern (2007)

\subsubsection{India}

India will certainly appeal to the same problematic, namely per capita or aggregate emissions. The country is even more negative than China to cut CO2 emissions, as it is in an earlier stage of industrialization and urbanization. Figure 6 shows the close connection between emissions and GDP for this giant nation. 


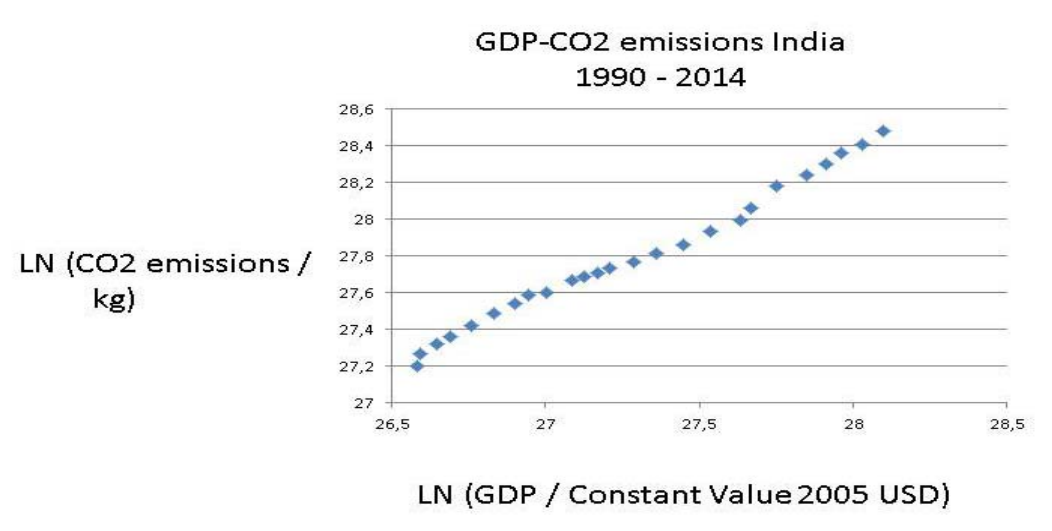

Figure 6. India: LN (CO2/ Kg and LN (GDP / Constant Value 2005 USD)(y = 0,77x + 6,79;

$$
\left.\mathrm{R}^{2}=0,99\right)
$$

India needs cheap energy for its industries, transportation and heating as well as air-conditioning (Figure 6), meaning it aims strongly at electrification. From where will this power come? India has water power and nuclear energy, but relies most upon coal, oil and gas as power source. It has strong ambitions for the future expansion of energy, but how is it to be generated, the world asks. India actually has one of smallest numbers for energy per capita, although it produces much energy totally. Figure 7 shows its energy mix where renewables play a bigger role than in China. However, the renewables in India may lead to deforestation and considerable pollution.
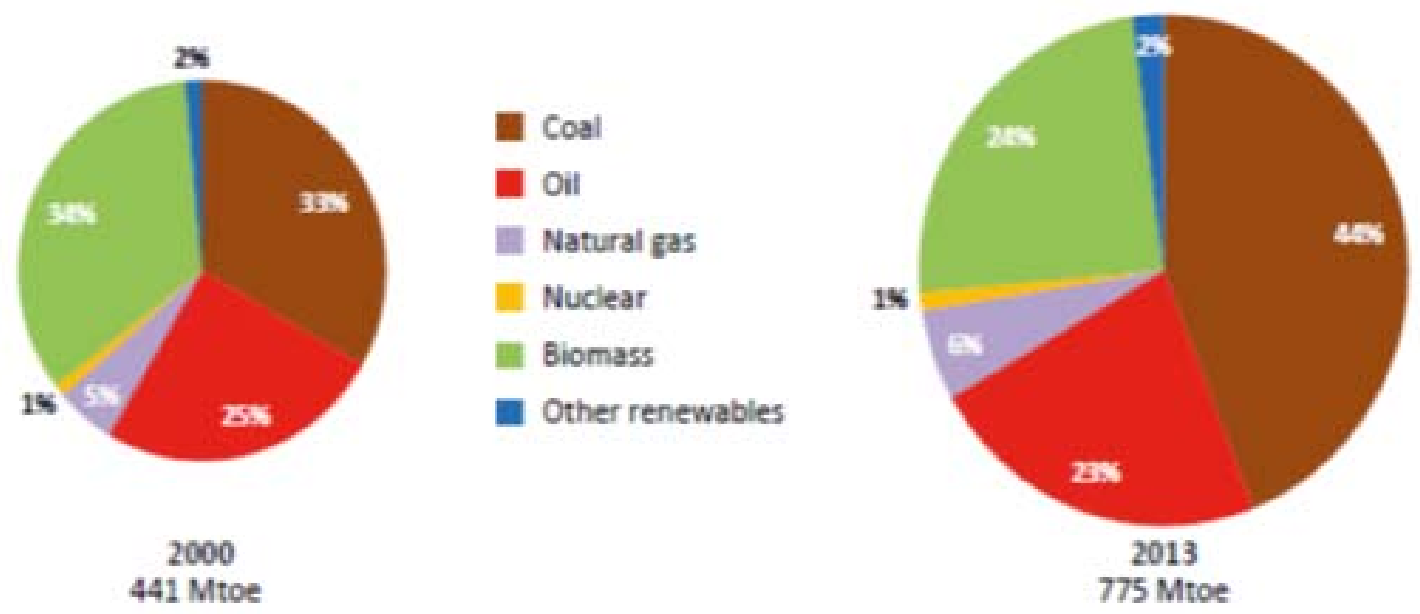

Figure 7. Primary energy demand in India by fuel

Source: http://www.eia.gov/beta/international/analysis.cfm?iso=IND

India needs especially electricity, as 300 million inhabitants lack access to it. The country is heavily dependent upon fossil fuels (70 per cent), although to a much less extent than China. 


\section{IIMacrothink}

Electricity can be generated by hydro power and nuclear power, both of which India employs. Yet, global warming reduces the capacity of hydro power-water shortages-and nuclear power meets with political resistance. Interestingly, India uses much biomass and waste for electricity production, which does not always reduce CO2 emissions. India's energy policy will be closely watched by other governments and NGO:s after 2018. The constant tension between the demand for economic growth on the one hand and environmental protection on the other hand is sharply portrayed in Ramesh (2015).

\subsubsection{Thailand}

One may guess correctly that countries that try hard to "catch-up" will have increasing emissions. This was true of China and India. Let us look at three more examples: Thailand, Malaysia and Iran-all emerging economies. Figure 8 begins with Thailand that has become a major car producer.

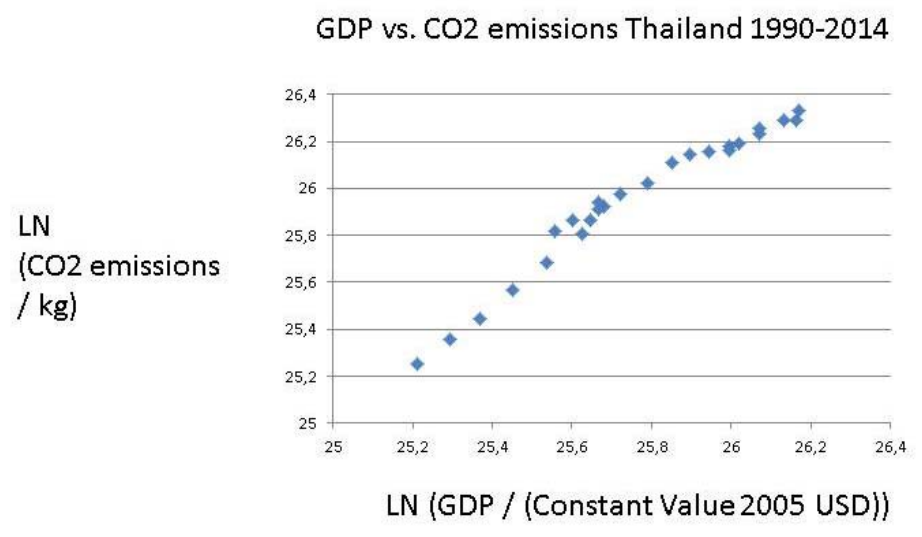

Figure 8. Thailand $\left(\mathrm{y}=1,07 \mathrm{x}, \mathrm{R}^{2}=0,96\right)$

The CO2 emissions in Thailand are quite high, reflecting the economic advances in South East Asia. The trend is up and up. Can it be reversed without serious economic impact? Figure 9 shows the energy mix of this dynamic country, economically. 


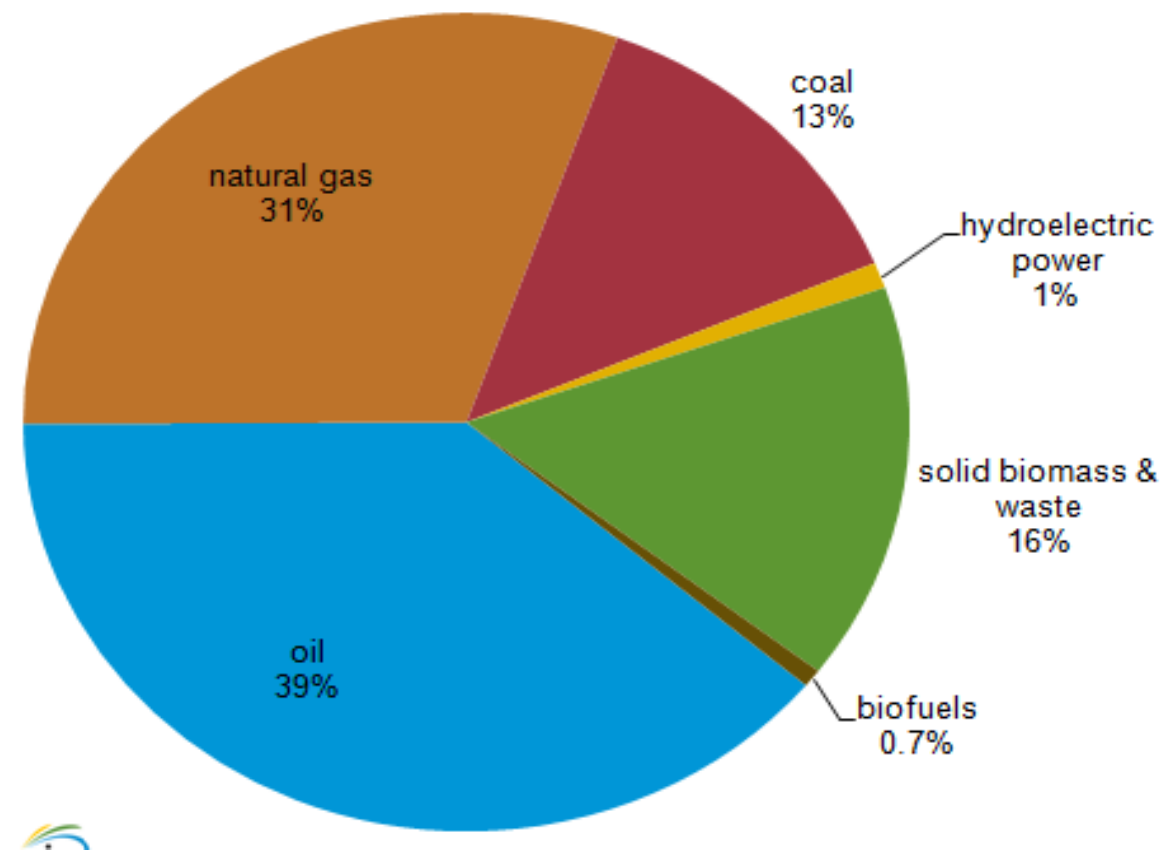

Figure 9. Total energy consumption in Thailand, by type (2010)

Source: EIA International Energy Statistics

The reliance upon fossil fuels is high, or over $80 \%$ of energy consumption coming from the burning of coal, oil and natural gas. Hydro power is marginal, but bio-energy plays a major role, but it is really not carbon neutral. Thailand needs to come up with far-reaching reforms of its energy sector in order to comply with COP21 objectives.

\subsubsection{Malaysia}

The overall situation - fossil fuels dependency - is the same for Malaysia as for Thailand. And the CO2:s are high, following the GDP trend (Figure 10).

GDP vs. CO2 emissions Malaysia 1990-2014

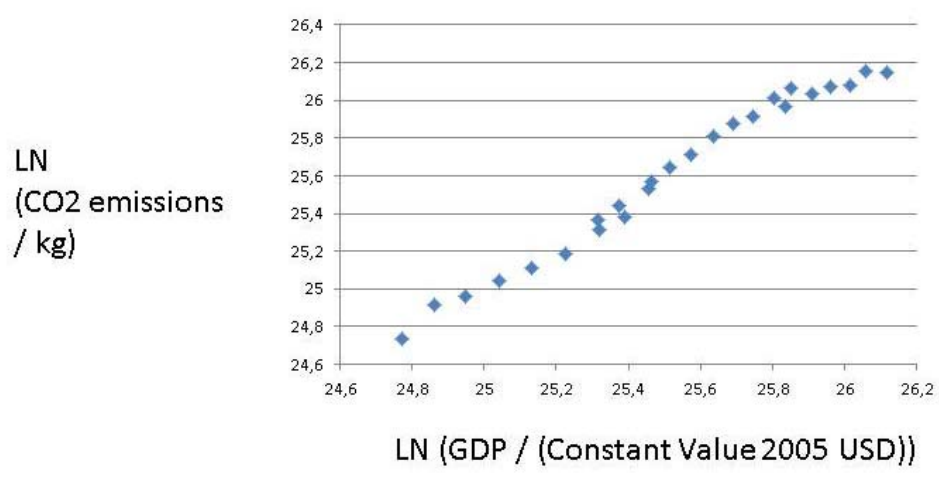

Figure 10. Malaysia $\left(y=1,13 x ; R^{2}=0,98\right)$ 


\section{Macrothink}

Business and Management Horizons

ISSN 2326-0297

2016, Vol. 4, No. 1

Yet, Malaysia employs energy of a very mixed bag (Figure 11), but still its emissions augment in line with economic development. There may be a planning out of the growth trend in emissions recently, but Malaysia use very little of carbon neutral energy sources. There is hydro power, but the country must move to solar and wind power rapidly.

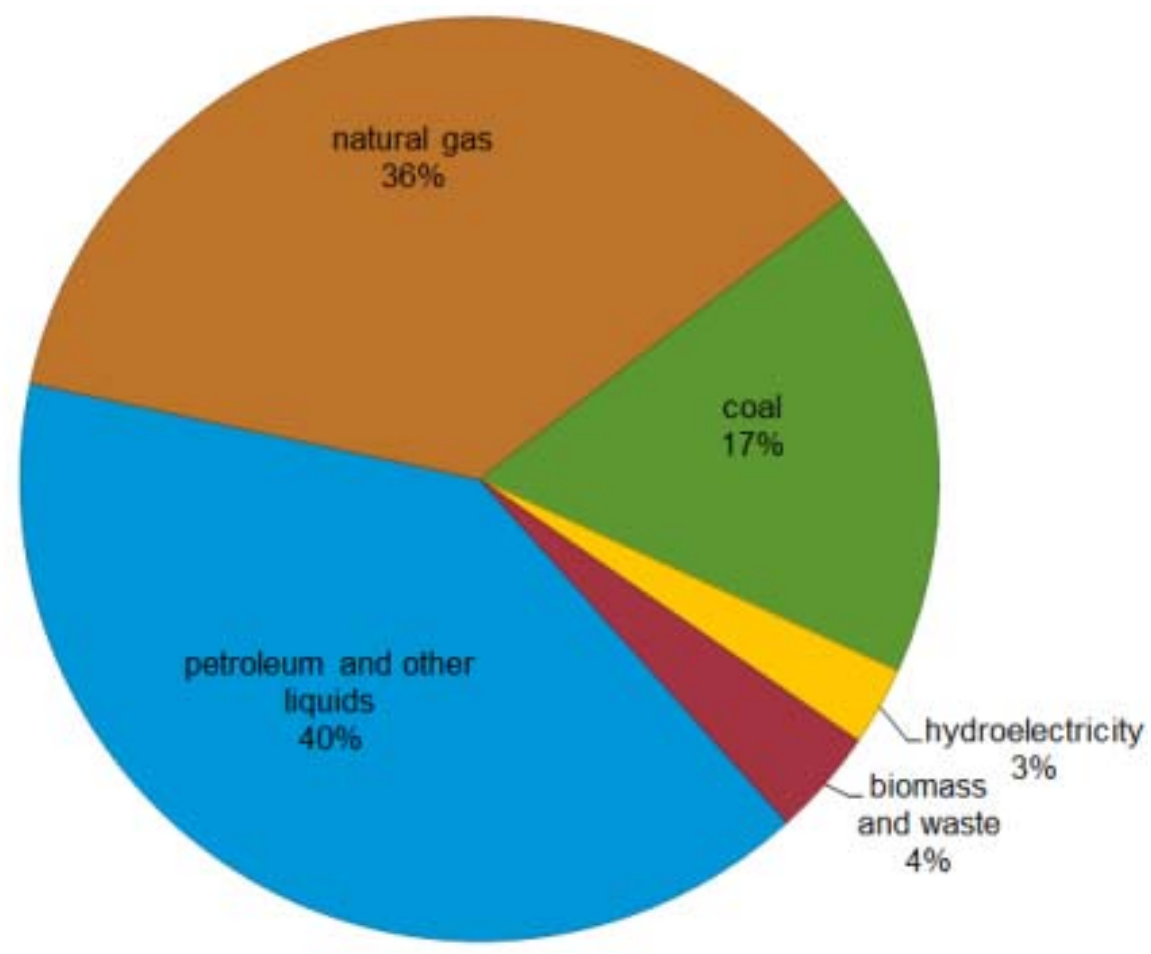

Figure 11. Malaysia’s primary energy consumption, 2012

Source: U.S. Energy information Administration

Renewables are not a major element in the energy consumption mix of Malaysia, as fossil fuels dominate, but not coal luckily.

\subsubsection{Iran}

Countries may rely upon petroleum and gas mainly_see Iran (Figures 12 and 13). CO2 emissions have generally followed economic development in this giant country, although there seems to be a planning out phase recently, perhaps due to the international sanctions against its economy. 
LN

(CO2 emissions

$/ \mathrm{kg}$ )
GDP vs. CO2 emissions Iran 1990-2014

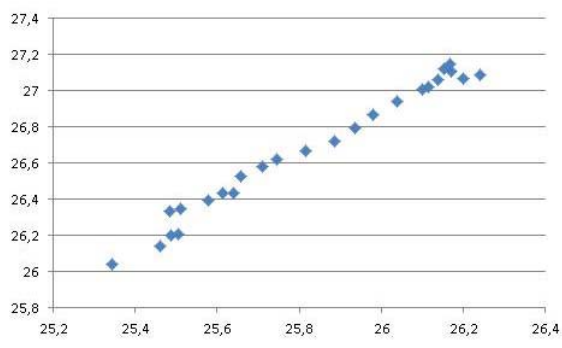

LN (GDP / (Constant Value 2005 USD))

Figure 12. Iran $\left(\mathrm{y}=1,2229 \mathrm{x}-4,91 ; \mathrm{R}^{2}=0,98\right)$

Iran is together with Russia and Qatar the largest owner of natural gas deposits. But despite using coal in very small amounts, its CO2 emissions are high. Natural gas pollute less than oil and coal, but if released unburned it is very dangerous as a greenhouse gas.

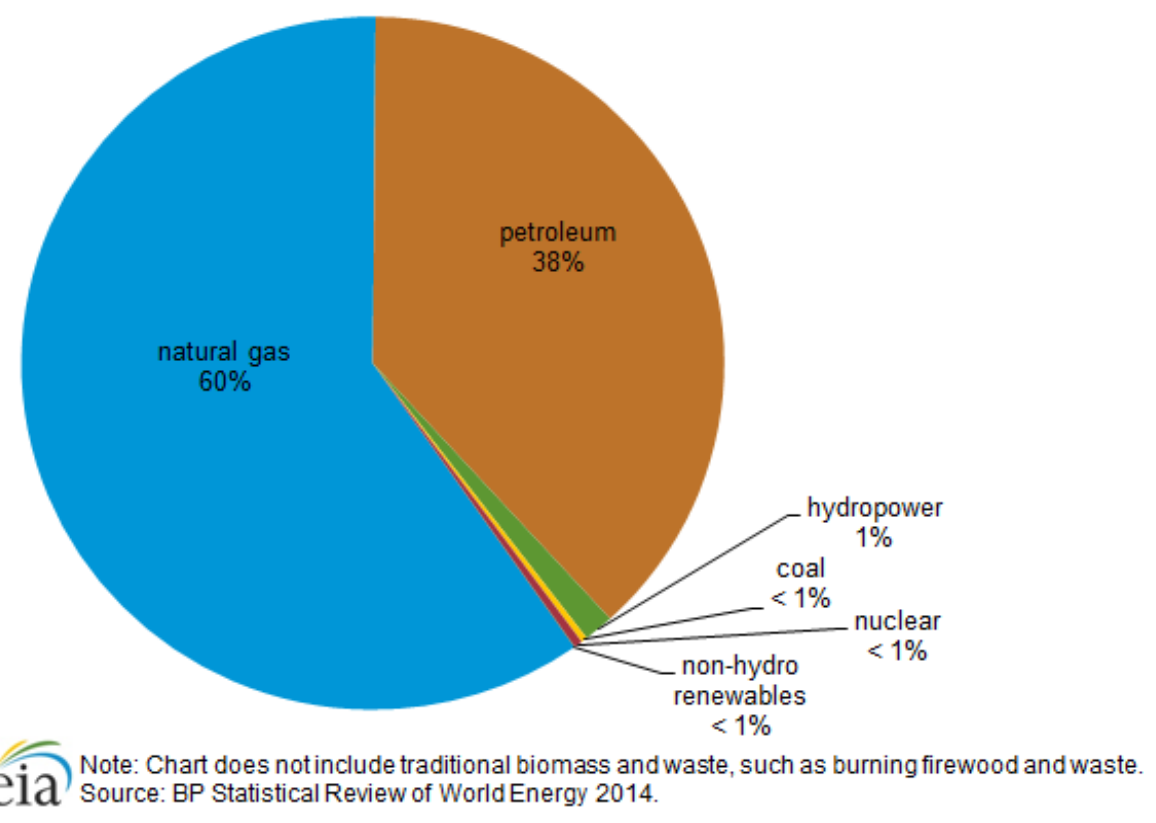

Figure 13. Iran’s total primary energy consumption, share by fuel 2013

Iran wants to export as much oil as it can, now that the sanctions have been lifted. And access to atomic power would help this strategy.

One may guess correctly that countries that try hard to "catch-up" will have increasing emissions. This was true of China and India. Let us look at three more examples, like e.g. giant Indonesia - now the fourth largest emitter of CO2:s in the world. 


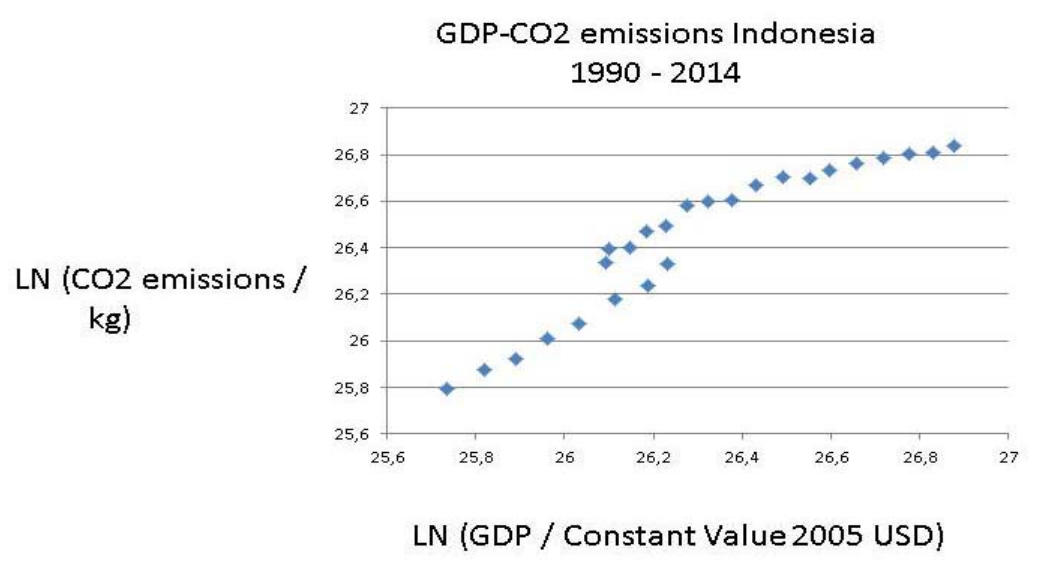

Figure 14. Indonesia: LN (CO2 / Kg and LN (GDP / Constant Value 2005 USD) (y = 1,69x;

$$
\left.\mathrm{R}^{2}=0,90\right)
$$

Indonesia is a coming giant, both economically and sadly in terms of pollution. Figure 9 reminds of the upward trend for China and India. However, matters are even worse for Indonesia, as the burning of the rain forest on Kalimantan augments the CO2 emissions very much. Figure 9 presents the energy mix for this huge country in terms of population and territory.

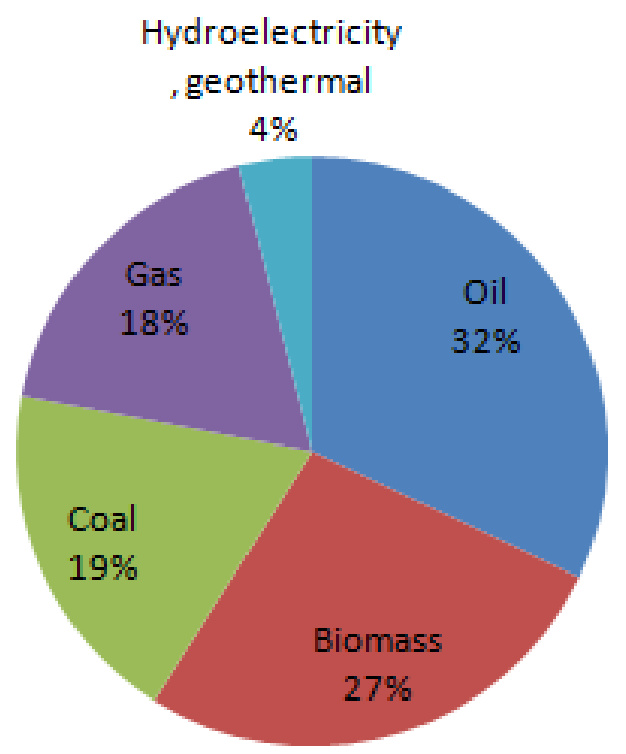

Figure 15. Distribution of Energy Consumption in Indonesia in 2009

Source: http://missrifka.com/energy-issue/recent-energy-status-in-indonesia.html

Only 4 per cent comes from hydro power with 70 per cent from fossil fuels and the remaining 27 per cent from biomass, which alas also pollutes. 


\section{Macrothink}

Business and Management Horizons

ISSN 2326-0297

2016, Vol. 4, No. 1

The same upward trend holds for another poor developing country with huge population, namely Pakistan: LN (CO2 / Kg and LN (GDP / Constant Value 2005 USD) (y = 1,05x - 0,97; $\left.\mathrm{R}^{2}=0,96\right)$. The amount of CO2 emissions is high for Pakistan, viewed as aggregate. Pakistan is mainly reliant upon fossil fuels, but not coal among them (Figure 16). Actually, it has a rather mixed bag of energy sources.

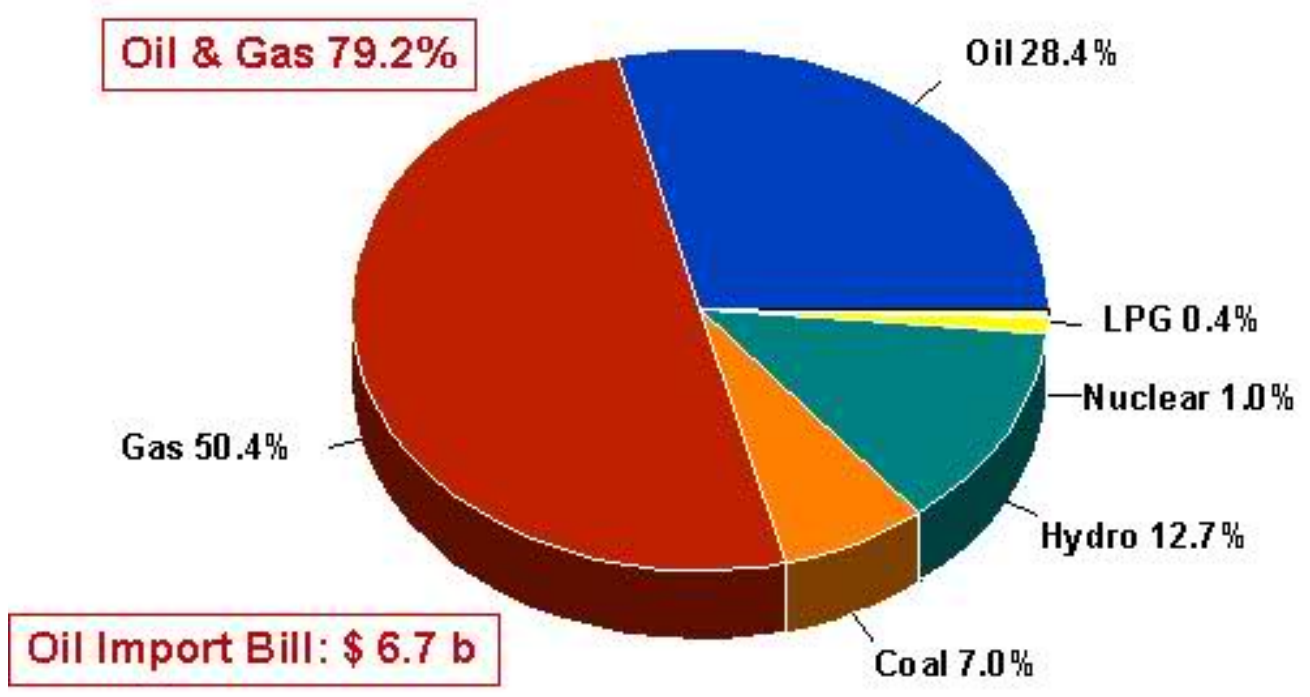

Figure 16. Pakistan Energy Consumption 2009 (by ShoXee: http://i27.tinypic.com/2h6cyag.jpg)

But Pakistan employs a considerable portion of hydropower-13 per cent-and a minor portion of nuclear power. Can it further develop nuclear and hydro power, or start using solar power on a large scale?

\subsection{North America}

\subsubsection{Canada}

Although Canada is a major emitter of CO2:s as well as one of the world's largest fossil fuel producer-oil sands, it has managed to stem the increase in emissions for the most recent years, i.e., halting the augmentation (Figure 17). Its energy mix may be invoked to explain this, showing a very mixed energy consumption pattern. 


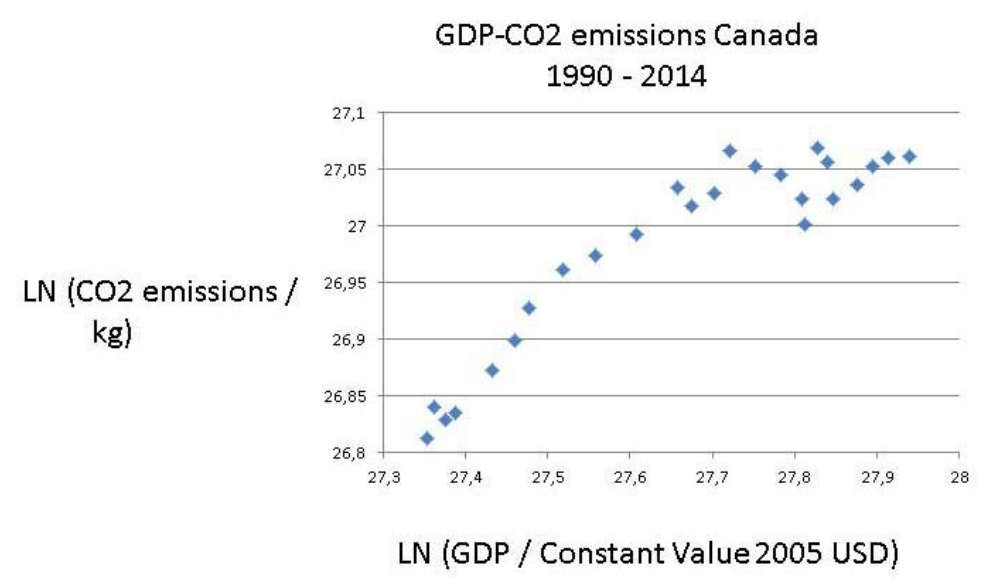

Figure 17. Canada: LN (CO2 / Kg and LN (GDP / Constant Value 2005 USD) (y = 0,41x + 15,$\left.7 ; R^{2}=0,85\right)$

Correctly, Canada has HALTED but not REDUCED CO2 emissions. There is often this confusion about $\mathrm{CO} 2$ emissions. To start reducing emissions, Canada may wish to eliminate coal and increase nuclear or renewables (Figure 18).

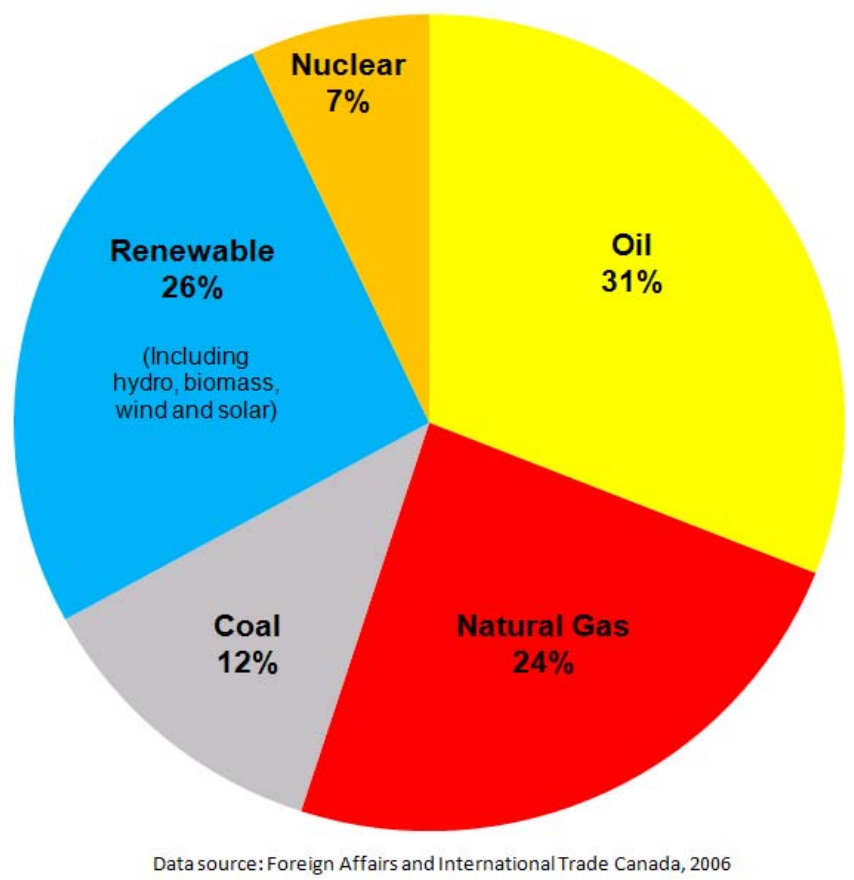

Figure 18. Canadian Energy Consumption by Primary Type 


\section{Macrothink}

Canada has a strong advantage compared with for instance China and India in that it has access to lots of hydro power and natural gas. The burning of coal is as low as 12 per cent, but oil still makes up almost a third of energy consumption.

\subsubsection{The US}

For most countries hold that their emission of CO2:s increases, as well as augments with the GDP. However, there are a few notable exceptions of decreases that are worth mentioning among the mature economies. We start with the US (Figure 19).

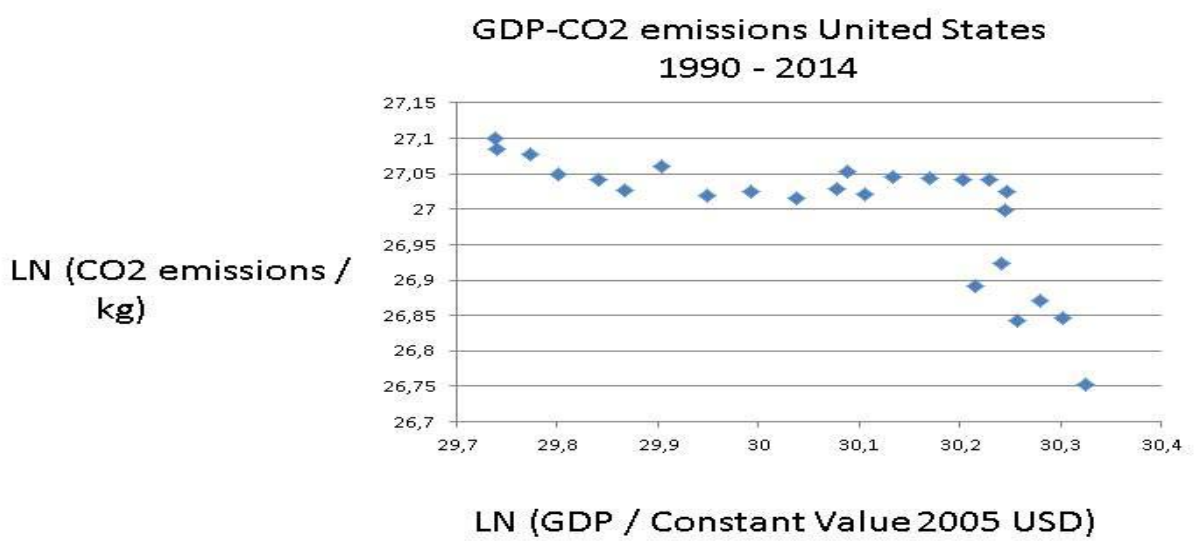

Figure 19. USA: LN (CO2 / Kg and LN (GDP / Constant Value 2005 USD) (y = -0,32x + 36,$\left.7 ; \mathrm{R}^{2}=0,49\right)$

Recently, the level of $\mathrm{CO} 2$ emission has been reduced significantly in the US. It reflects no doubt partly the economic crisis that began 2007, but the US remains the second largest polluter in the world. The reduction reflects that the US can draw upon a mixed bag of energies including nuclear and hydro power, with solar power expanding rapidly (Figure 20). Per capita CO2:s is of course very high for the USA. As the economy now starts to accelerate, emissions are bound to go up again, unless solar power stations multiply dramatically over the country. 


\section{quadrilion Btu}

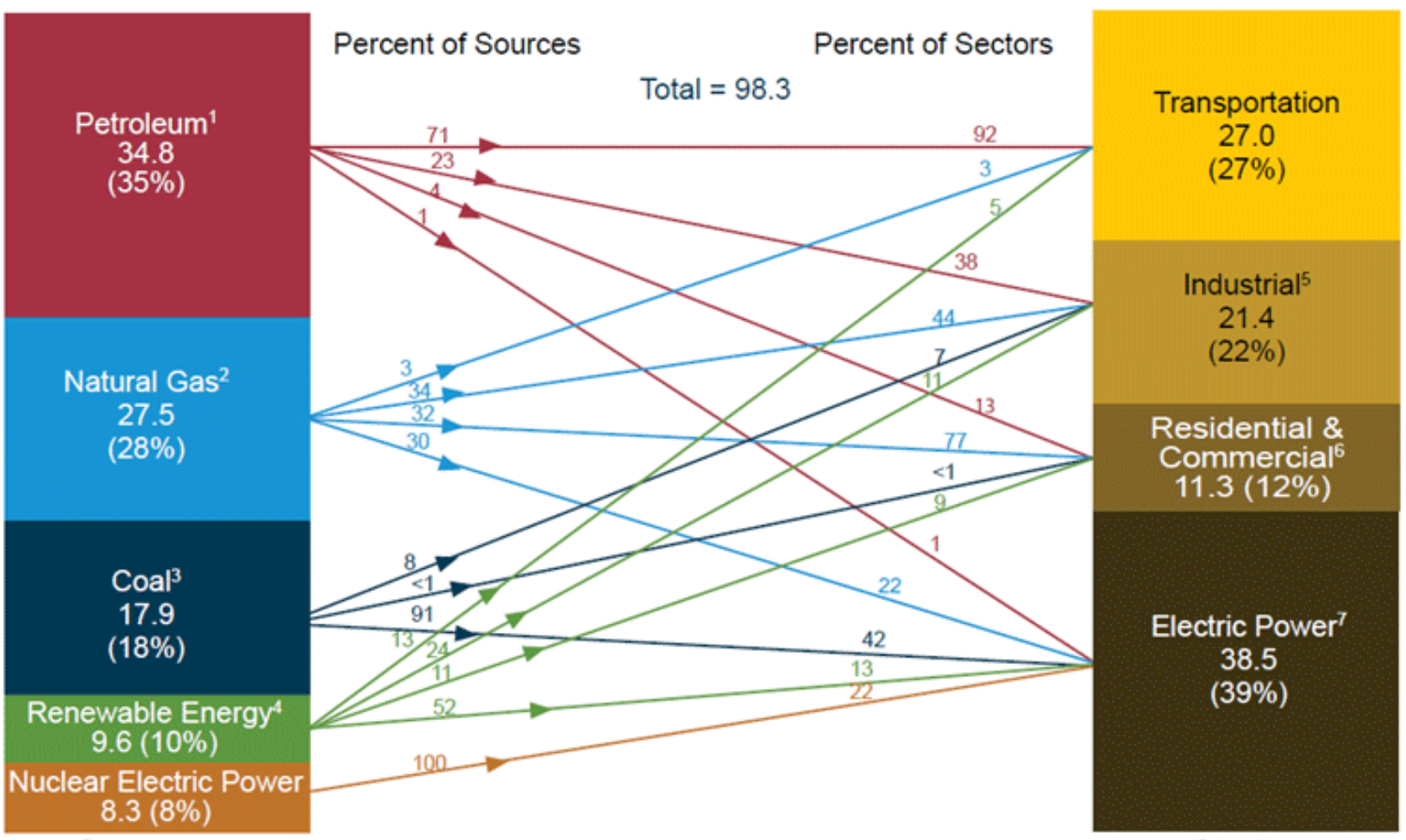

Source

Sector

Endnotes:

${ }^{1}$ Does not include biofuels that have been blended with petroleum-biofuels are included in

"Renewable Energy."

${ }^{2}$ Excludes supplemental gaseous fuels.

${ }^{3}$ Includes less than -0.1 quadrillion Btu of coal coke net imports.

${ }^{4}$ Conventional hydroelectric power, geothermal, solar/photovoltaic, wind, and biomass.

${ }^{5}$ Includes industrial combined-heat-and-power (CHP) and industrial electricity-only plants.

${ }^{6}$ Includes commercial combined-heat-and-power (CHP) and commercial electricity-only plants.

${ }^{7}$ Electricity-only and combined-heat-and-power (CHP) plants whose primary business is to sell electricity, or electricity and heat, to the public. Includes 0.2 quadrillion Btu of electricity net imports not shown under "Source."

Notes: Primary energy in the form that it is first accounted for in a statistical energy balance, before any transformation to secondary or tertiary forms of energy (for example, coal is used to generate electricity). - Sum of components may not equal total due to independent rounding.

Sources: U.S. Energy Information Administration, Monthly Energy Review (March 2015), Tables 1.3, 2.1-2.6.

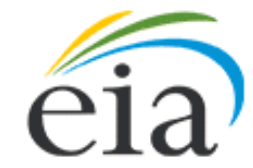

Figure 20. Primary energy consumption by source and sector, 2014

The US is still heavily dependent upon fossil fuels, or some 80 per cent comes there from. What is changing is the more and more of energy is produced within the US and no longer imported from outside- the shake oil and gas revolution. Further reduction of CO2:s may meet with firm resistance from the Republican House of Congress, which may oppose the 


\section{Macrothink}

COP21 Agreement, like presidential candidate D. Trump. However, solar power should be attractive in many US states, both in micro use in households and large plant use.

The advent of shale oil and gas has changed the entire energy markets, lowering the price of oil most substantially. This implies not only that there will be no Hubbert peak oil for the world, but also that switching to renewable energy source will be extremely expensive, relatively speaking compared with shale oil and gas. When petroleum is abundant, then investments in carbon neutral power sources may be non-lucrative and require massive state subsidies.

Figure 20 shows how important energy is to the entire US society, including for its superpower position. When further reductions in CO2:s threaten vital national interests, the US like other nations will no doubt employ fossil fuels.

\subsection{Latin America}

\subsubsection{Mexico}

One would expect to find huge $\mathrm{CO} 2$ emissions in this large emerging economy with lots of oil production. Countries like the Gulf States have massive CO2:s because they drill and refine oil and natutal gas. For Mexico holds the following situation (Figure 21).

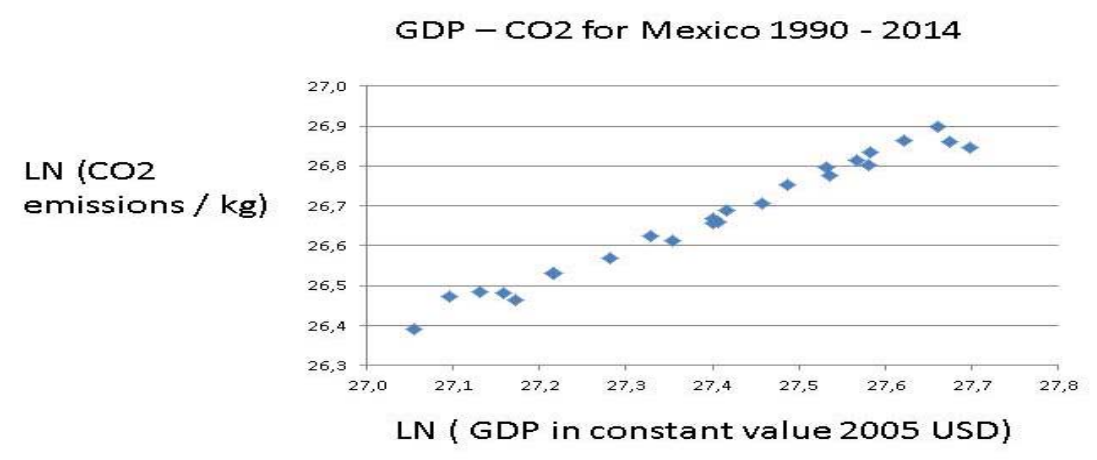

Figure 21. GDP-CO2 in Mexico: $y=0,77 x ; R^{2}=0,98$

The close link between economic development and CO2 is discernable in the data, but the emissions growth seems to stagnate in the last years. This is of course a promising sign, whether it is the start of a COP21 inspired 40\% reduction in CO2:s remains to be seen. I doubt so, but let us enquire into the energy mix of this huge country that is of enormous economic importance to both North and South America. 
Total energy consumption in Mexico by type, 2014

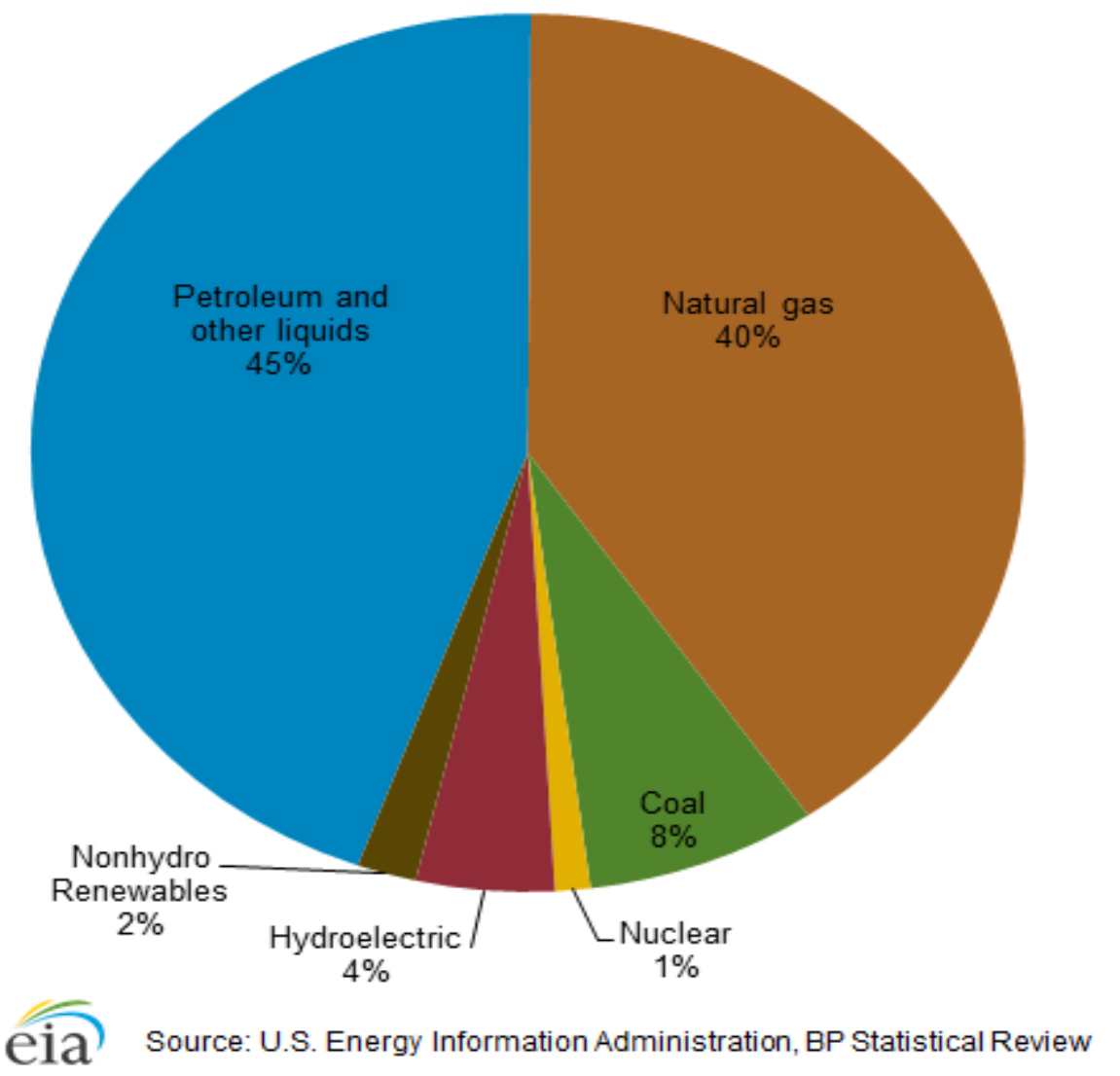

Figure 22. Energy mix for Mexico

Few countries are so deependent upon fossil fuels as Mexico. One find the same patter with the Gulf States. The Mexican government must start now to reduce this dependency, by for instance eliminating coal and bringing down petreoleum, instead betting upon solar, wind and nuclear power. Mexico will face severe difficulties with the $40 \%$ reduction target in COP21. It has a fast growing population with many in poverty and an expanding industry sucking electricity. Can economic growth and decarbonisation go together here?

\subsubsection{Brazil}

Let us now look at the ethanol country par preference: Brazil. Figure 15 shows a considerable levelling out of total emissions, but it is followed by huge increases, mirroring the GDP development. 


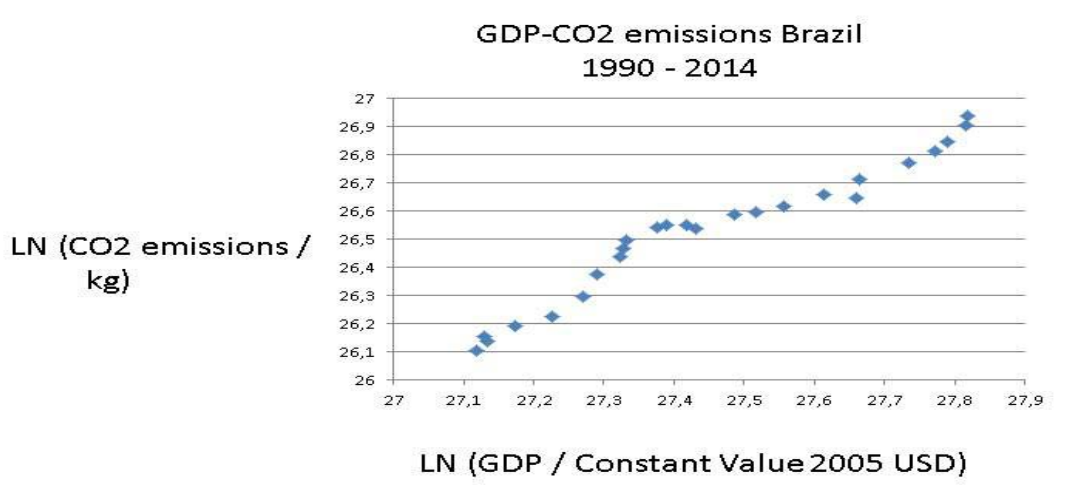

Figure 23. Brazil: LN (CO2 / Kg and LN (GDP / Constant Value 2005 USD)(y = 1,029x -

$$
\left.1,72 ; \mathrm{R}^{2}=0,95\right)
$$

Brazil employs the most biomass in the world—ethanol, but the emissions stay at a very high level, which is a reminder that renewables may also lead to CO2:s. One advantage for Brazil is the large component of hydro power, but the overall picture for the largest Latin American country is not wholly promising, when it comes to reduction of emissions. Yet, global warming reduces the potential of hydro power, and Brazil has very little nuclear power (Figure 16). There are plans for mega hydro projects in the Amazon basin, but Brazil has first and foremost to come to terms with the extensive deforestation of this huge rain forest, contributing a lot to global warming.

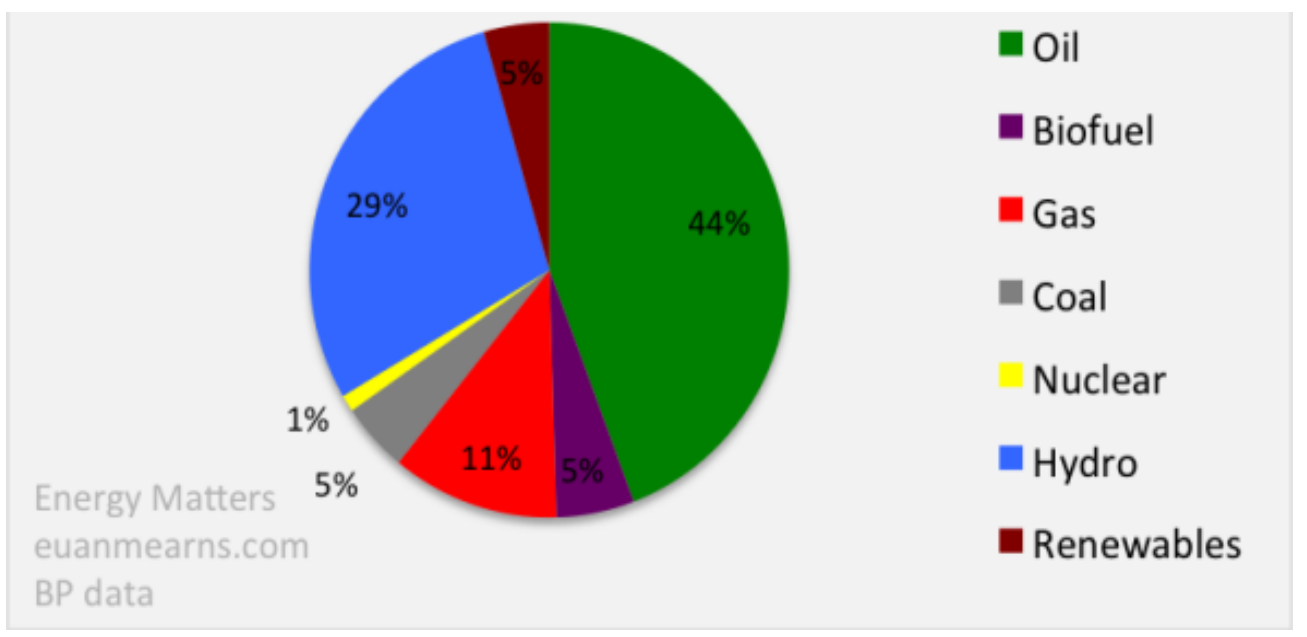

Figure 24. Brazil energy consumption 2013

I believe most "emerging economies" rely much upon fossil fuels, like the examples above. Bur how about some "mature economies"? 


\section{Macrothink}

4.4 The EU

\subsubsection{Germany}

Another interesting country is the largest EU economy, namely Germany. Figure 25 shows a marked decrease in $\mathrm{CO} 2$ emissions.

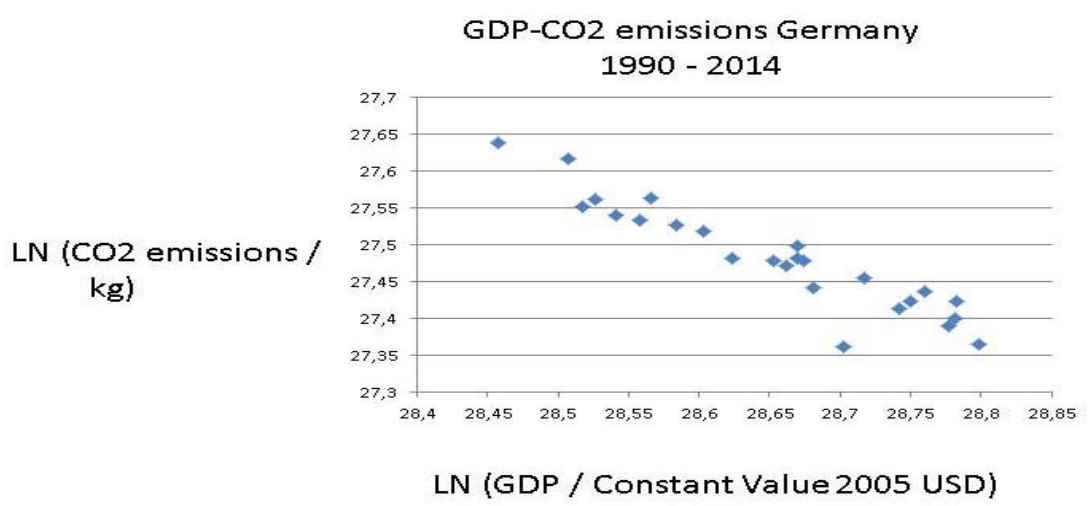

Figure 25. Germany: LN (CO2 / Kg and LN (GDP / Constant Value 2005 USD) (y = -0,69x + 47,$\left.3 ; R^{2}=0,88\right)$

The German data shows an impressively consistent decreasing trend, which is not to be found with many countries, if at all. How come that Germany has succeeded in a short time span to reduce CO2:s? Germany needs massive amounts of energy for industry and transportation, but it has decided to phase out nuclear power. Can really the domestic employment of renewables satisfy this giant's demand for electricity (Figure 27 below)? German energy policy-ENERGIWENDE-is spectacular comparatively speaking, but it also appears risky indeed.

It is true that nuclear power and renewables has made it possible for Germany to decrease its CO2:s much, but the country is still dependent upon fossil fuels, especially coal and oil-almost $60 \%$. What will happen with the nuclear power stations are phased out in 2022 is that most likely the CO2 emissions will start going up again. To replace nuclear power with solar and wind power on a truly massive scale will be difficult to say the least. Already, Germany uses more coal from Columbia and gas from Russia.

The German energy policy is causing much stir, because the losers-nuclear industry and coal power interests—-want compensation that will run into billions of dollars, if not more.

\subsubsection{France}

Interestingly, also France has like Germany managed decarbonisation to some extent (Figure 23). It reflects its unique energy mix, relying much upon nuclear power in a comparatively unique way. 


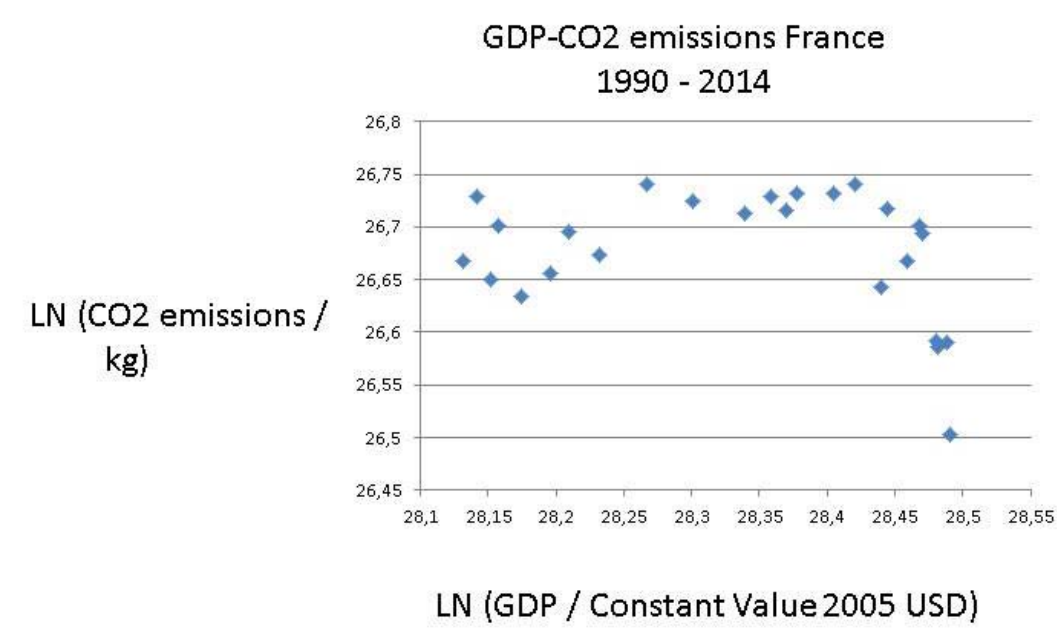

Figure 26. France $\left(y=-0,13 x+30,4 ; R^{2}=0,08\right)$

Yet, France has decided to diminish its reliance upon nuclear power. But how will it be replaced by other sources of energy? Figure 23 infroms about the reliance upon fossil fuels in Germany and France too. 


\section{Macrothink}

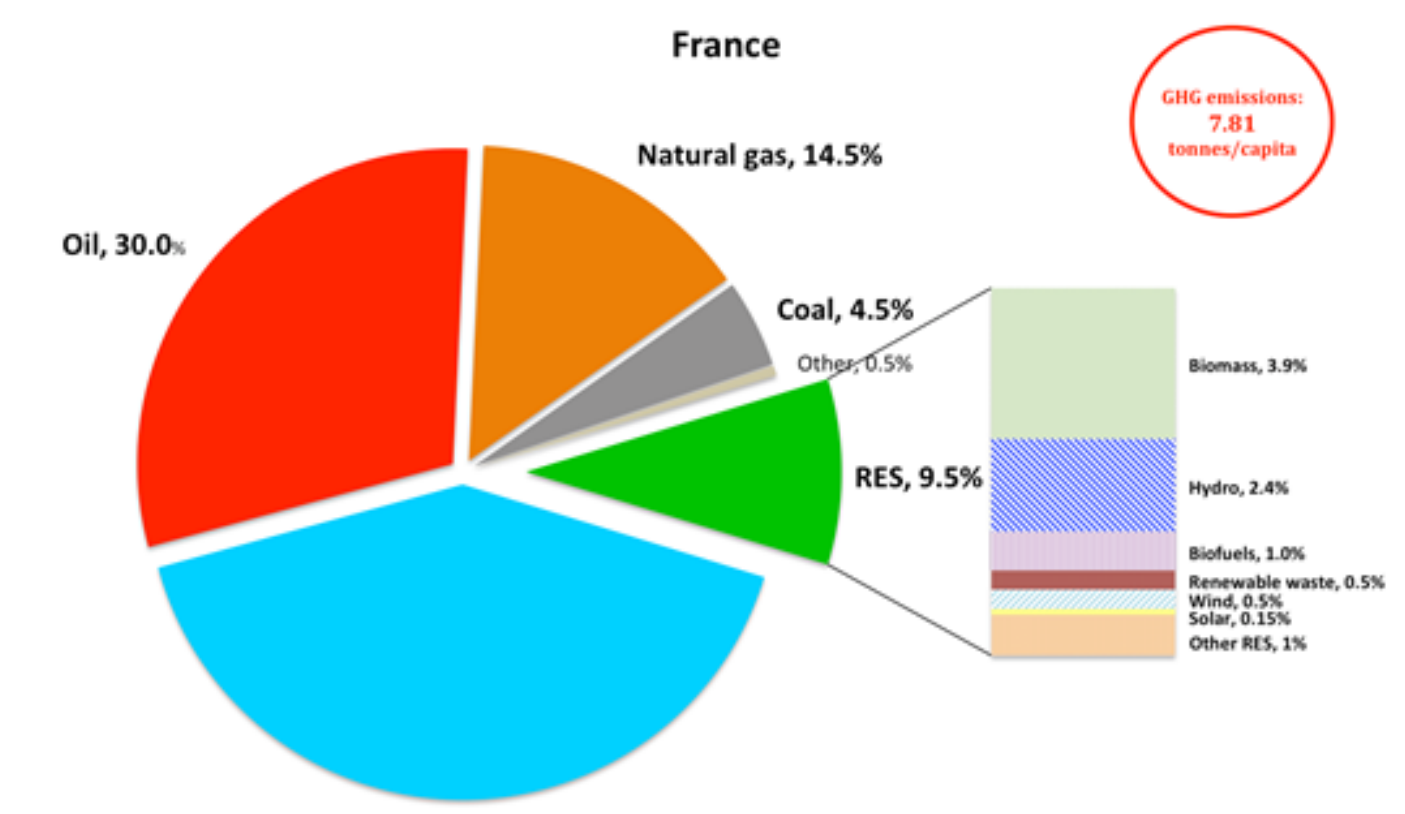

Nuclear, $41.0 \%$

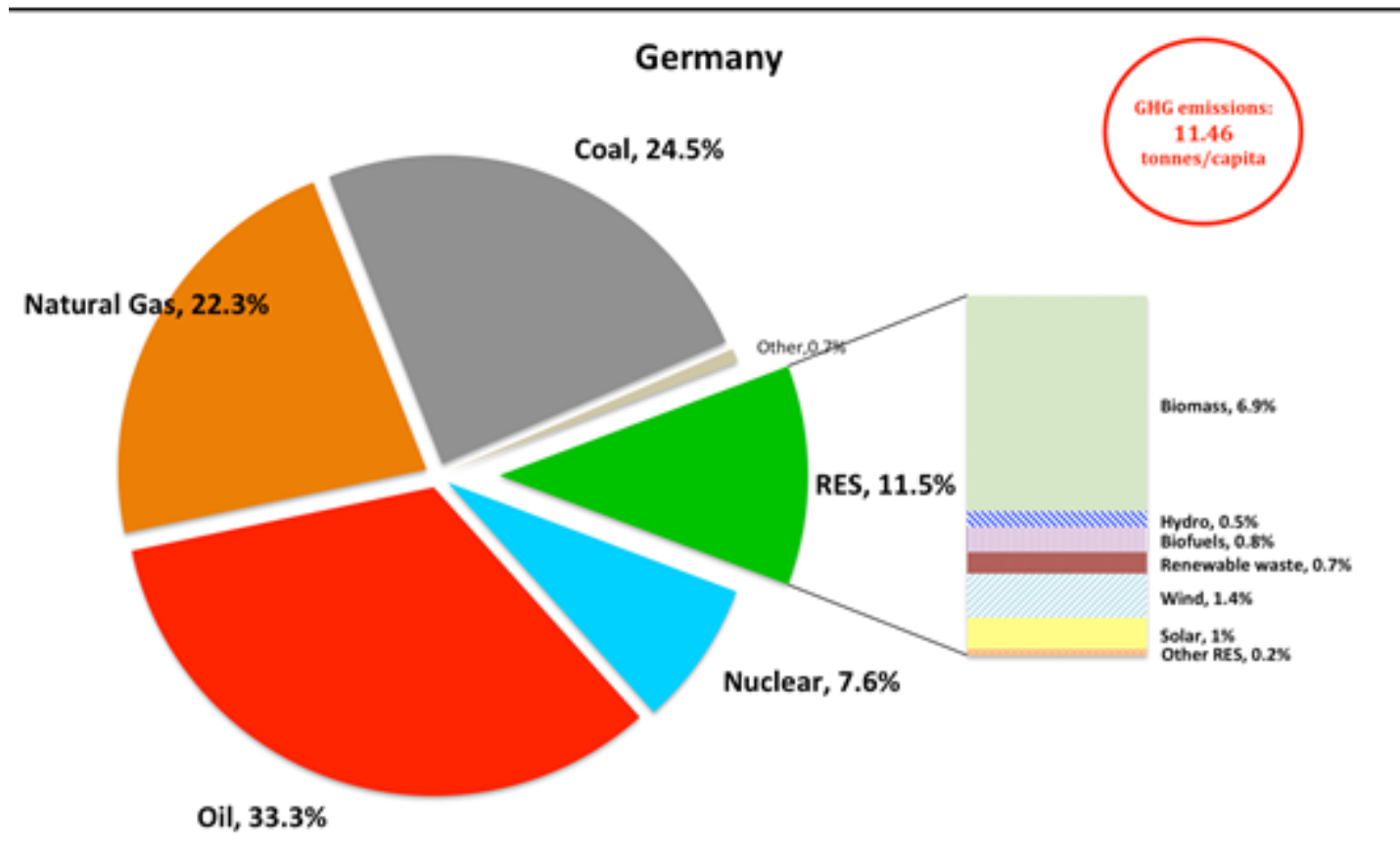

Figure 27. Mixes of energy

Source: http://blog.iass-potsdam.de/2015/05/energy-transition-france-following-in-germanys-footsteps/

As underlined, no other country in the world employs nuclear power to such an extent (Figure 23), allowing France to avoid lost of CO2:s. But the Green movement's criticism of nuclear power is based upon entirely different argument than the wish to decarbonise economy and society. Actually, doing both-decarbonisation and de-nuclearisation-may prove difficult for France.The French energy sector-EDF and AREVA - has suffered immensely from lower energy prices and scepticism about nuclear power, requiring massive state support. 


\subsection{Africa}

As many African countries have reached their "take-off" stage, they need energy, especially electricity. Yet, the African scene is highly diverse, with on the one hand economic success stories and on the other hand the spread of anarchy and lawlessness. For the environment on the African continent, both energy exploitation and criminals', rebels' or terrorists' activities are negative events all the time, resulting in poaching and loss of animal habitat. Let us look at the emissions-energy situation in a few countries that are stable: Egypt, Algeria and South Africa.

Egypt has a huge population with high unemployment and mass poverty besides a certain level of political instability, resulting from religious conflicts. But surely it has electricity from inta giant Assuam dam and the Nile? No, it does not coult for much where most people live in the Nile delta (Figure 28).

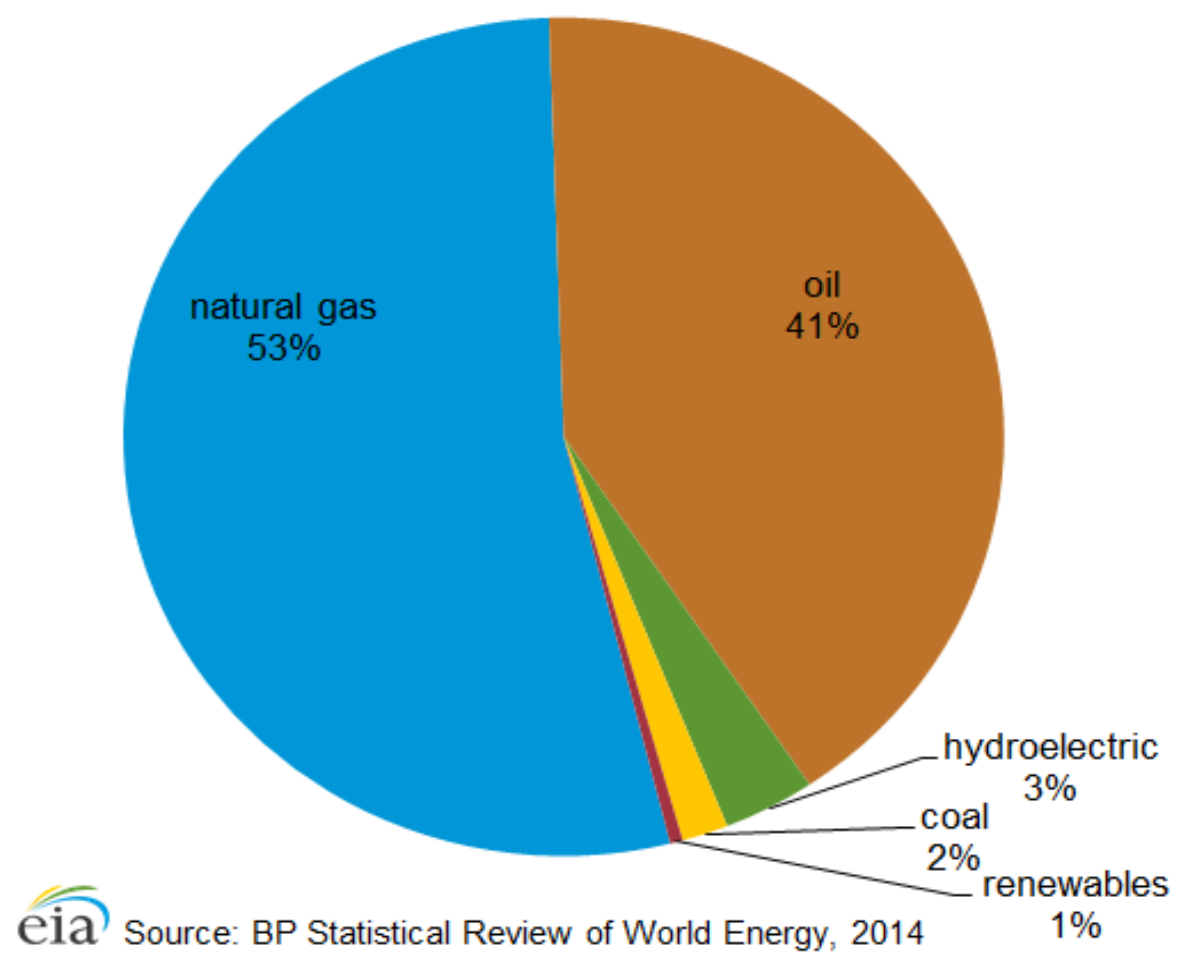

Figure 28. Primary energy consumption in Egypt, by fuel, 2013

The share of hydro power is stunning low for a country with one of largets rivers in the world. Actuallu, the water of the Nile is the source of interstate confrontation between Egypt, Sudan and Ethiopia.

As Egypt relies upon fossil fuels, it has massive $\mathrm{CO} 2$ emissions, the trend of which follows its GDP (Figure 29). 


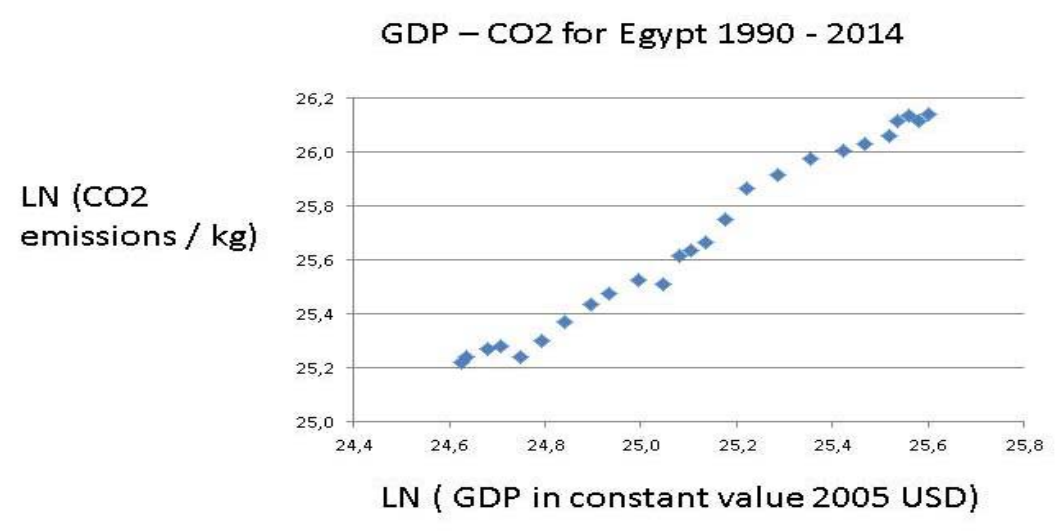

Figure 29. GDP-CO2 for Egypt: $y=1,02 x ; R^{2}=0,99$

It will be very difficult for Egypt to make the COP21 transformation, at least without massive external support. But where to build huge solar power plants in a country with terrorism, threat or actual?

Algeria is a major exporter of natural gas and oil, Thus, we expect that it relies mainly on fossil fuels, like Mexico and the Gulf States. Figure 30 verifies this expectation.

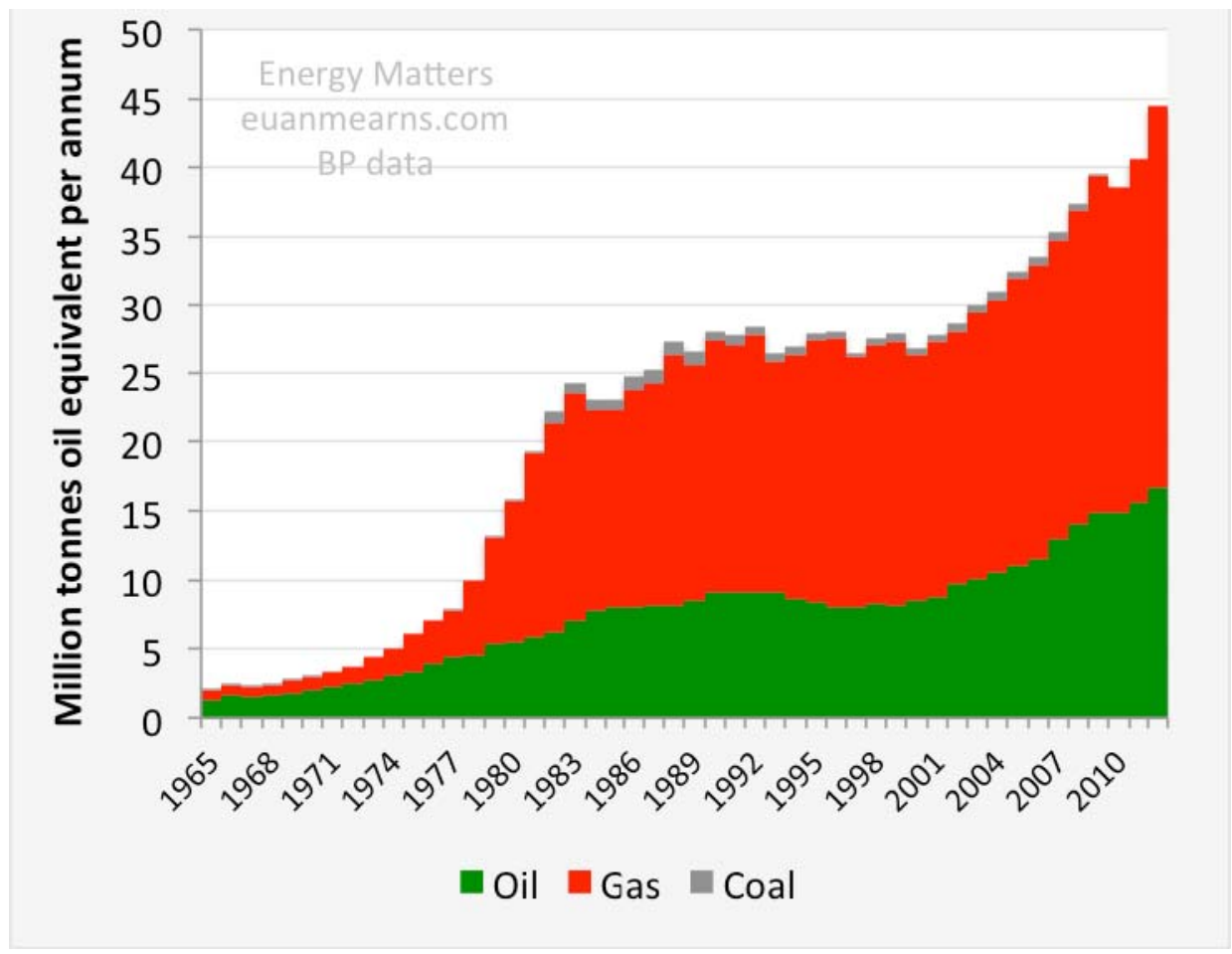

Figure 30. Algeria primary energy consumption

Source: http://euanmearns.com/post-peak-algeria/ 


\section{Macrothink}

Business and Management Horizons

ISSN 2326-0297

2016, Vol. 4, No. 1

Although Algeria may trust in the availability of future fossil fuels resources, it still faces the demand for a $40 \%$ reduction of its $\mathrm{CO} 2$ emissions. They have thus farfollowed the economic progress—see Figure 31.

GDP - CO2 for Algeria $1990-2014$
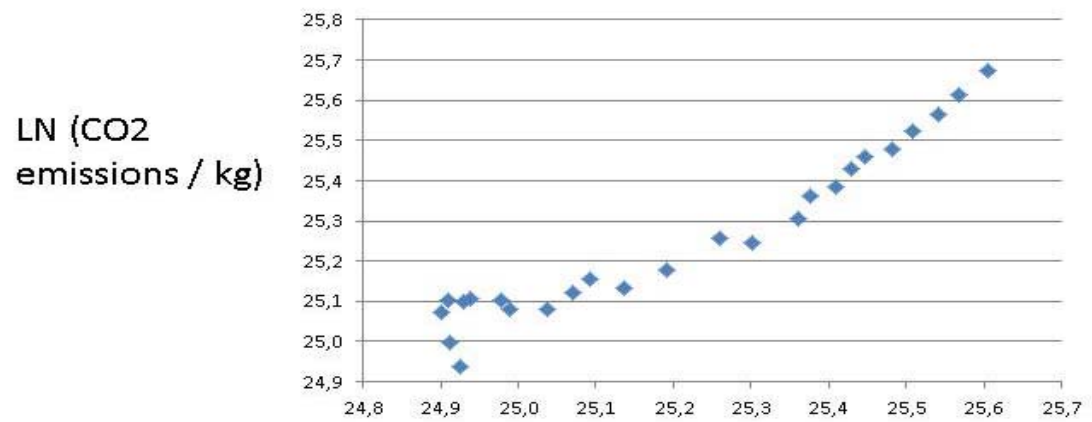

LN (GDP in constant value 2005 USD)

Figure 31. GDP-CO2 in Algeria: $y=0,81 x ; R^{2}=0,93$

One would naturally suggest solar energy as a viable alternative to the heavy dependence upon fossil fuels in Algeria, given its immense Saharan territory. Yet, also Algeria has been plagued by the attacks of terrorists or looters.

An enormous reliance upon traditional renewables is to be found also in Angola and Nigeria, although both have access to both hydro power and fossil fuels. Figure 32 describes the energy mix for Angola.

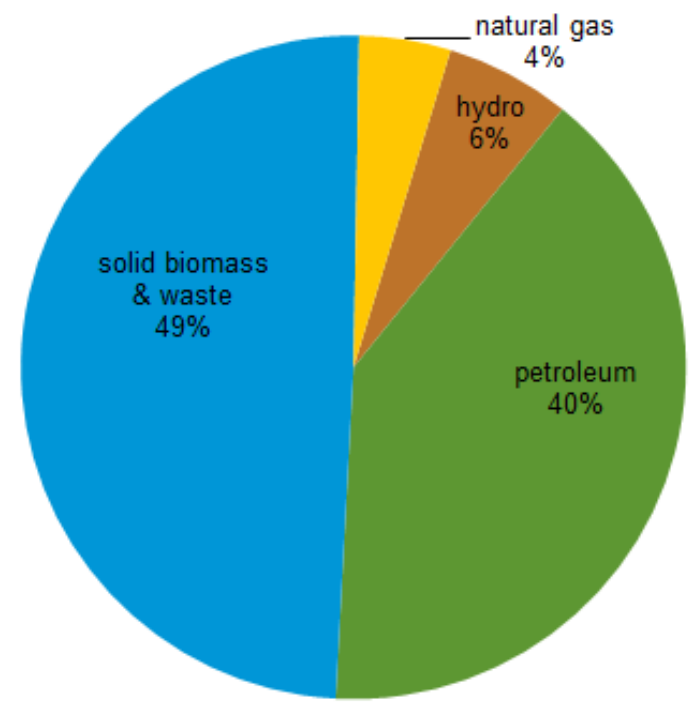

eia Source: U.S. Energy Information Administration and International Energy Agency

Figure 32. Angola’s primary energy consumption, 2012 


\section{Macrothink}

Angola like Kongo has suffered from long and terrible civi war. In the mass of poor villages, energy comes from wood, charcoal and dung - all with negative environmental consequences. Angola has immense fossil fuels - oil and gas, but the political elit family may prefer to export these resources instead of using them for electricity generation. Giant Nigeria has a resembling energy mix-see Figure 33.

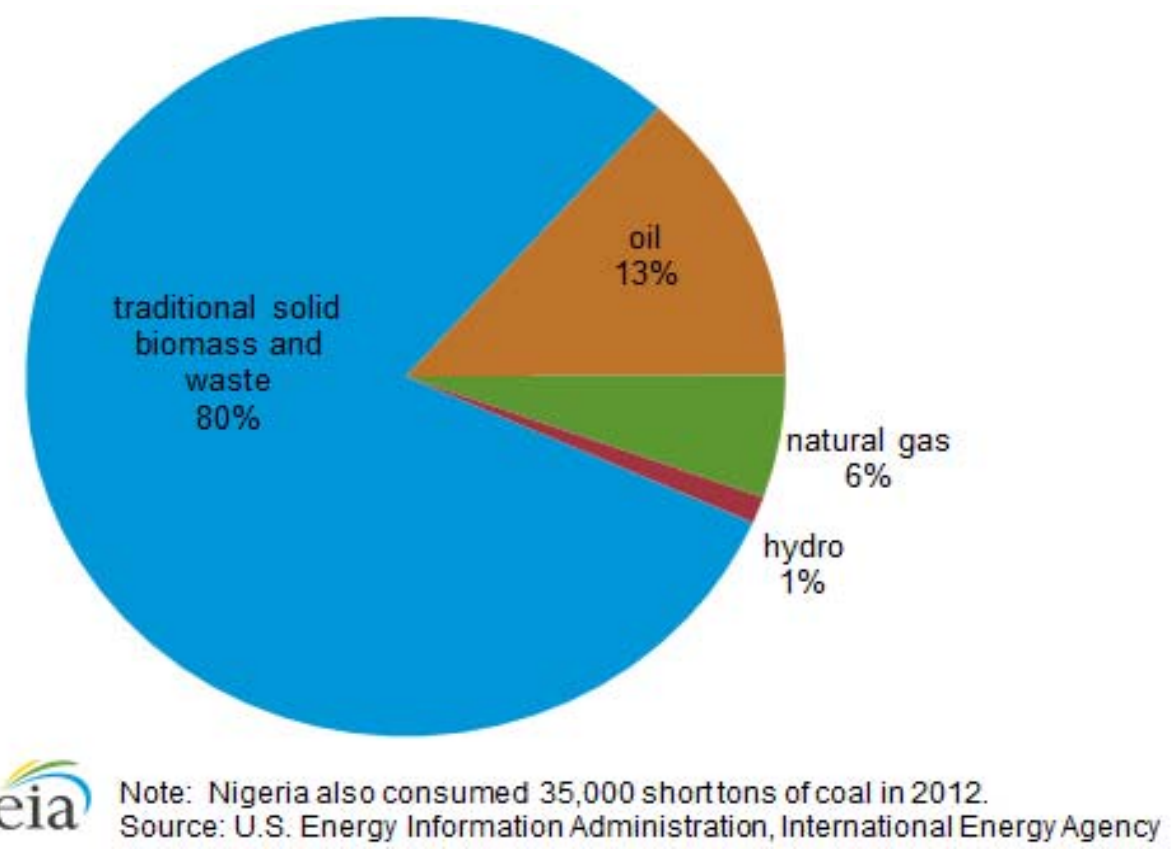

Figure 33. Nigeria’s total primary energy consumption, 2012

Nigeria would have to diminish the use of traditional renewables in order to meet the COP21 goals. The very same policy recommendation applies to two countries in the Nile valley, namely Sudan and Ethiopia-extremely poor countries relying mainly upon traditional renewables

The COP21 framework outlines the three main goals for the 21rst century in order to keep Planet Earth habitable. Thus, these 3 objectives are now accepted as desirable, but scholars now question whether they are feasible, at least without massive costs or economic decline and global depression. A few countries are almost completely dependent upon coal. How will they implement the COP21 goals? Look at South Africa. Emissions are high, because South Africa uses a lot of coal to generate electricity (Figure 34). Decarbonisation will be difficult and costly. The reliance upon coal in this largest economy in Africa is stunning. 


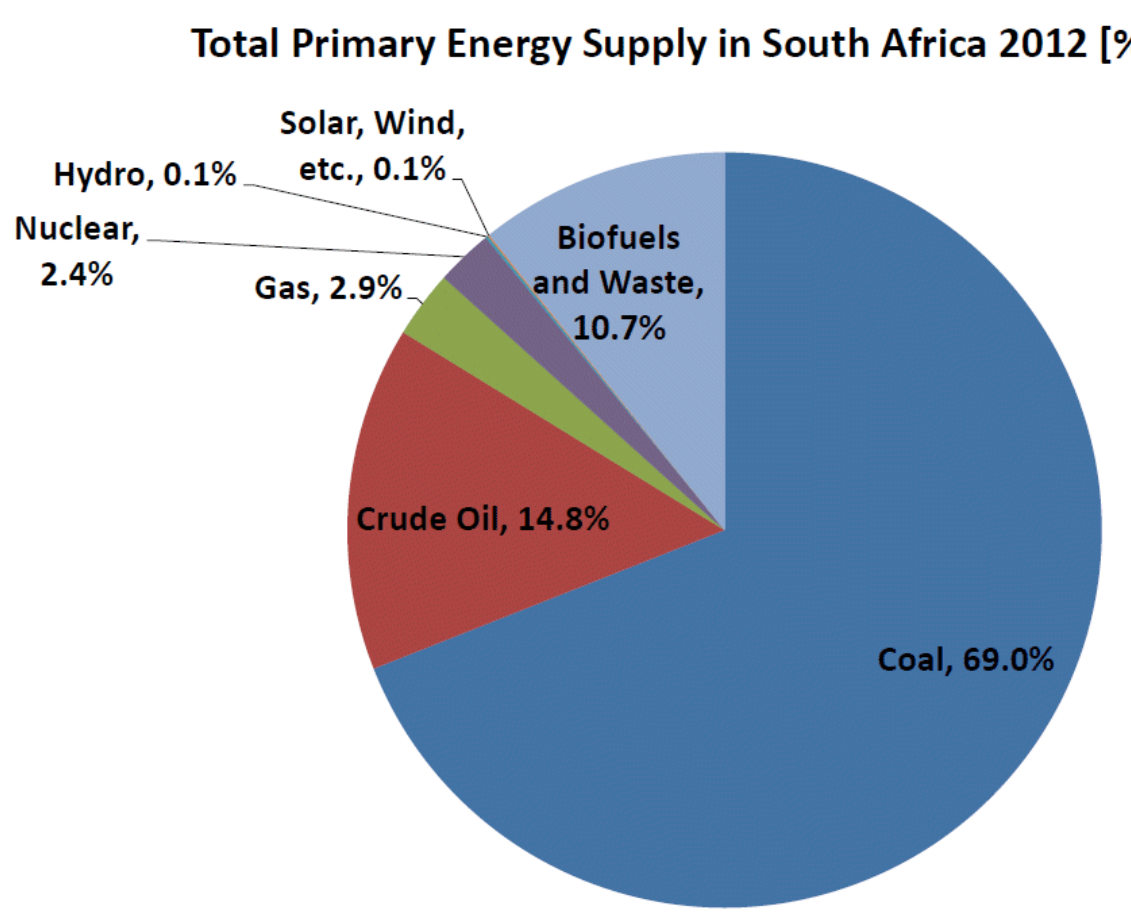

Figure 34. Energy consumption in RSA

Does the RSA have the resources and motivation to cut the coal consumption radically and move to solar energy for instance? Or could the RSA renege-the always available option in collective action endeavours?!

\subsection{The Gulf}

The states around the Persian Gulf-kingdoms and emirates_-have advanced economies, producing large amounts of CO2:s—see Figure 35for Saudi Arabia. However, they also wish to demonstrate a green ambition.

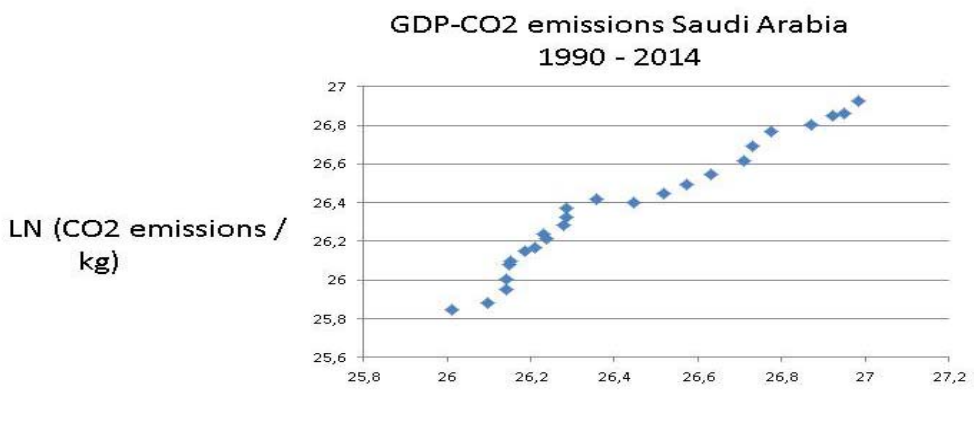

LN (GDP / Constant Value 2005 USD)

Figure 35. Saudi Arabia $\left(y=1,03 x-0,77 ; R^{2}=0,95\right)$ 


\section{Macrothink}

The Saudis like the Emirates rely upon two kinds of fossil fuels, oil and gas (Figure 34). And they use lots of cement for their magnificent buildings, like Dubai and Abu Dhabi.

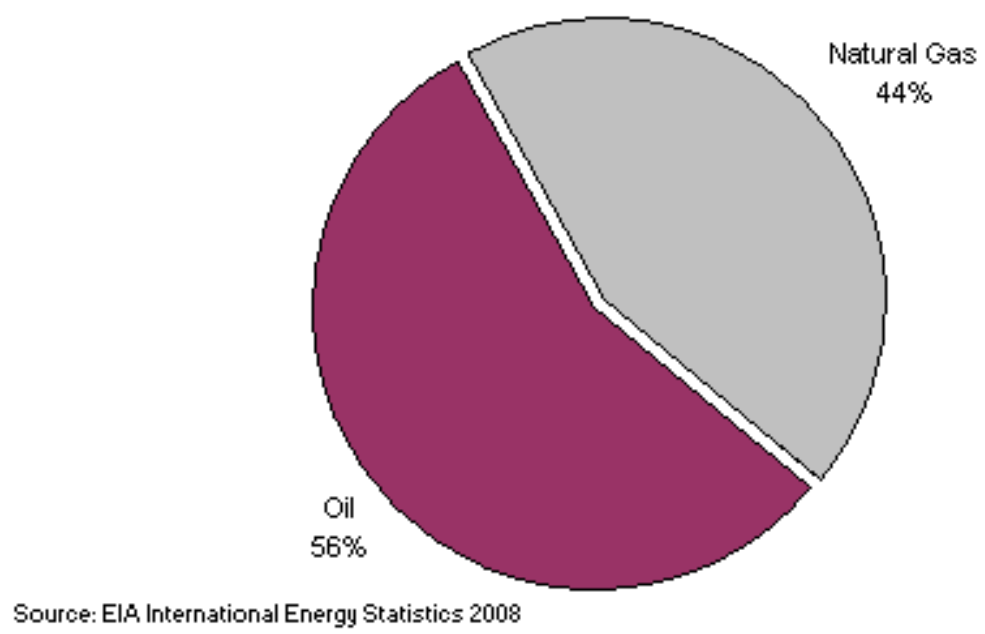

Figure 34. Total Energy Consumption in Saudi Arabia, by Type (2008)

Moreover, the UAE have increased their emission of CO2 sharply in relation the positive economic development of these emirates. They rely upon the fossil fuels of Abu Dhabi with immense oil resources. Like other Gulf States, the UAE boosts with building entirely GREEN sites, with energy from solar power and resulting in almost no waste. But it is based upon their enormous consumption of electricity, generated out of burning oil and gas. Saudi Arabia will diversify into nuclear power with help from South Korea.

\section{Towards Green Economic Growth?}

Scholars who argue that we can have both decarbonisation and economic growth bet upon the arrival of both more energy efficient technologies and technological innovations that lead to more energy but have little emissions of greenhouse gases. Thus, nuclear power plants can be built in such a way that the risk of a melt-down is excluded. And solar power gets all the time cheaper and more reliable.

Yet, in relation to the COP21 Agreement there is cause for much pessimism. It is true that small changes are feasible, replacing fossil fuels with renewables, but we are talking about the need for large scale transformation. These stylised projections for 2030, the year of COP21, are completely outside of its objectives of a 40\% reduction of CO2 emissions.

The CO2:s can only be reduced through decarbonisation of the economy in a wide, which can be promoted through:

- A zero growth economy or "sustainable economy" with Sachs, but it is not likely to occur; 
- A massive transition to solar, wind and nuclear power, which would require enormous new investments. Large scale solar and wind power needs huge space and are vulnerable to sabotage;

- A reduction in global output, meaning recessions. It will be avoided by governments by all means necessary.

The link between economic growth and environmental protection has been much debated in public policy and environmental economics. One may identify four positions:

- Positive: growth makes environmental protection feasible - rapid growth promotes environmental care;

- Negative: economic development uses up environmental resources or assets - zero growth economy;

- Contingency: it depends upon the particular project whether the impact is positive or negative;

- Trade-off: often development projects result in some economic gains against some environmental losses.

Examining the literature, one finds scholars advocating all four positions (Managi, 2015; Sachs, 2015; Eriksson, 2012; de Bryun, 2012). Probably one can find examples of all four types of combination between growth and environment in all countries: e.g., Indian solar panel parks, Chengdu Park for pandas, Jakarta harbour protection wall, opening up coal mines in tiger sanctuaries in India, burning down the rain forest in Kalimantan for agriculture, building the enormous dam-Three Gorges Dam in China, etc. But, as Indian expert Ramesh (2015) underlines, the question of emissions, energy and economic development involves a trade-off between environment and growth. One may certainly fear that many governments will renege upon COP21 when faced with a choice between economic growth and green sustainability.

In the policy sciences and management theory, an enquiry into the relationship between means and ends is most often of central interest, when examining governmental decisions, whether domestic or international ones. This relation is of a causal nature, the means either being conducive to the achievement of the goals, or not. Goal accomplishment consists of arriving at outcomes that fulfill the goals. This is one of classical models in the social sciences, emphasizing actions and their alternatives, probabilities or degree of effectiveness and outcomes or real life results. Some link with the methodological individualism of Max Weber, while others frame it more ambitiously in the rational choice with homo economicus. In any case, it is a most suitable model for evaluating policies or policy decisions, targeting the implementation of objectives.

The UN or its UNFCCC and the world governments have arrived at a complex policy, referred to as the COP21. It is now up for decentralized implementation by the various national governments with an overview function for a special body of the UN. The stated means include: 
a) Decreasing the CO2:s by 40 per cent until 2030

b) Moving towards a total decarbonisation of the economy and society in the second half of the 21rst century.

In policy-making, you often encounter so-called means-end chains: The ultimate objectives are to be accomplished by a set of means M1 and these M1 are in turn to be achieved by another set of means M2. In the COP21, the 40\% reduction and the total decarbonisation are to be promoted by the following means:

c) Elimination of energy sources that emit heavy CO2:s;

d) Replacement with new energy sources that are carbon neutral: solar, wind and geo-thermal power;

e) Financial assistance by means of a Stern like Superfund for helping Third World countries do c) and d) without much damage to their economies.

The idea is that projects c) and d) shall start 2020, although the exact form of the UN supervisory body and the superfund has yet to be decided, together with other oversight measures, like controls, evaluations, advice, in order to stem reneging. If some major car companies can cheat with emissions, why would not certain governments engage in opportunistic behavior with guile?

The causal theory implicit in this means-end chain with both M1 and M2 is that global warming is mainly the result of anthropogenic greenhouse gases, especially CO2:s, which in turn comes from economic activities around the world in a wide sense. Thus, the base model is the following:

GDP is linked with energy consumption that is conducive to $\mathrm{CO} 2$ emissions.

One may examine the means in a policy in at least two ways. First, are the means recognized and intended really effective, meaning furthering the goals in question? Second, have all the relevant means been considered for the achievement of the objectives? Whereas we will concentrate upon the analysis of the first question below, we wish to strongly underline that the entire COP21 framework bypasses another very dangerous GHG, namely methane.

Methane makes up some $20 \%$ of the greenhouse gases. It is party anthropogenic, resulting for instance from agriculture (cows, pigs, and poultry), party natural, as pockets of methane are unlocked from frozen seabed or land sites, as a function climate change. If vast amounts of methane are released from the oceans or the tundra, the COP21 will definitely fail in halting global warming. As the implementation of the COP21 objectives moves ahead, much more attention has to be paid to the methane problematic, not only in agriculture.

\section{Conclusion}

Once the cornucopian theory about climate change was rejected due to both empirical and theoretical reasons, the governments of the countries in the world came around to sign the COP21 Agreement. This is global governance policy declaration: objectives, promises and 
commitments. Strictly speaking, it is only talk.

The fate of the COP21 framework lies in the implementation process that now starts and is supposed to go on during almost the entire century until complete decarbonisation is reached.

Thus far, COP21 is merely promise. Only the implementation process can tell whether decarbonisation will be accomplished, according to the objectives. Implementation may fail due to faulty information, contrary preferences or opportunistic behaviour with guile. My guess is that there will occur lots of reneging on the COP21 framework, despite its true relevance for the future of mankind.

The global situation is now that CO2 emissions do not increase so fast in relation to the GDP, so that one could even speak of a slow halting of its growth. But this is far from enough for the COP21 objectives. The curve in Figure 36 must start turning downwards quickly. Can, then, economic development continue to advance as before? If not, the costs of fighting climate change will be high, but the costs of doing nothing may be even higher. There is so much talk about economic growth in the world mass media that one fear that the economic development will trump climate stability.

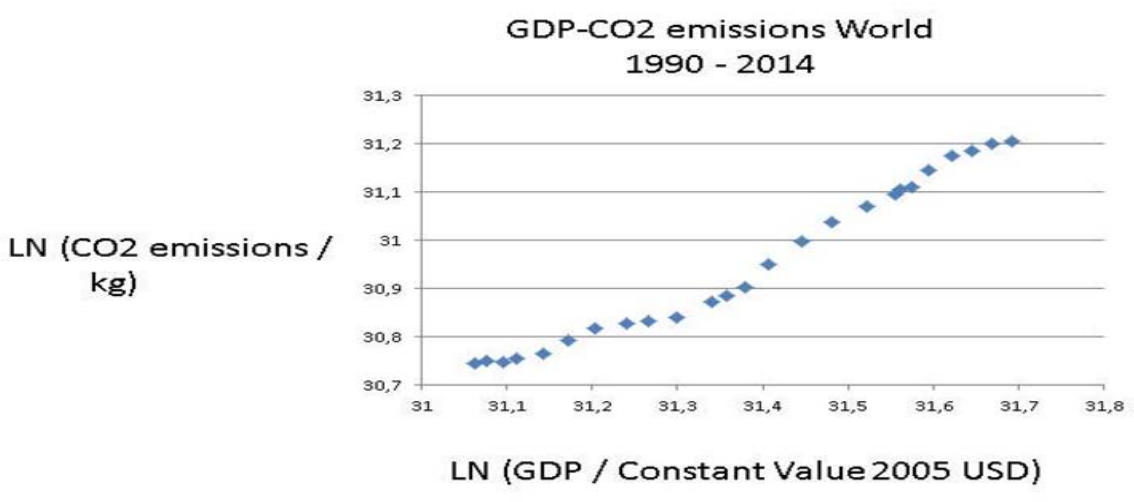

Figure 36. The Global Scene (Equa.: $\left.y=0,77 x+6,79 ; \mathrm{R}^{2}=0,99\right)$

It is often that the growth in $\mathrm{CO} 2$ is stalling now, but the reality is that some countries can reduce whereas others keep expanding $\mathrm{CO} 2$ emissions. Energy as capacity to do work is the key.

\section{Sources}

\section{GDP, GHG:}

World Bank national accounts data - data.worldbank.org

OECD National Accounts data files

World Resources Institute CAIT Climate Data Explorer—cait.wri.org 
EU Joint Research Centre Emission Database for Global Atmospheric Research—http://edgar.jrc.ec.europa.eu/overview.php

UN Framework Convention on Climate Change_http://unfccc.int/ghg_data/ghg_data_unfccc/time_series_annex_i/items/3814.php

BP Energy Outlook

\section{Energy data}

Energy Information Administration. Washington, DC.

International Energy Agency. Paris IEA: Key World Energy Statistics

\section{Footprint, Bio-capacity:}

Global

Footprint

Network

(https://www.google.com/?client=gmail\#q=global\%20footprint\%20network\&authuser=0)

Living Planet Report 2014. Global Footprint Network, WWF, Zoological Society of London.

Living Planet Report 2008. GFF. The Ecological Footprint Atlas 2008.

United Nations Population Division. World Population Prospects, United Nations Statistical Division.

Population and Vital Statistics Report (various years), Census reports and other statistical publications from national statistical offices

Eurostat: Demographic Statistics

Secretariat of the Pacific Community: Statistics and Demography Programme,

U.S. Census Bureau: International Database

\section{References}

de Bruyn, S. M. (2012). Economic Growth and the Environment: An Empirical Analysis. Berlin: Springer.

Eriksson, C. (2013). Economic Growth and the Environment: An Introduction to the Theory. Oxford: OUP. http://dx.doi.org/10.1093/acprof:osobl/9780199663897.001.0001

Lomborg, B. (2007). Cool It. The Sceptical Environmentalist's Guide to Climate Change. New York: Alfred Knopf.

Managi, S. (2015). The Routledge Handbook of Environmental Economics in Asia. London: Routledge.

March, J., \& Olsen, J. (1976). Ambiguity and Choice. Oslo: Universitetsforlaget.

Mazmanian, D. A., \& Sabatier, P. A. (1989). Implementation and Public Policy. Lanham, MD: UPA. 


\section{Macrothink}

Business and Management Horizons

ISSN 2326-0297 2016, Vol. 4, No. 1

Pressman, J., \& Wildavsky, A. (1973, 1984). Implementation. Berkeley: University of California Press.

Ramesh, J. (2015). Green Signals: Ecology, Growth and Democracy in India. Oxford: Oxford U.P. http://dx.doi.org/10.1093/acprof:oso/9780199457526.001.0001

Sabatier, P. A. (1988). An advocacy coalition framework of policy change and the role of policy-oriented learning therein. Policy Sciences, 21, 129-168. http://dx.doi.org/10.1007/BF00136406

Sachs, J. (2015). Sustainable Development for Humanity's Future. [Online] Available: http://jeffsachs.org/2015/08/sustainable-development-for-humanitys-future/

Sachs, J. D. (2015). The Age of Sustainable Development. New York: Columbia University Press.

Simon, J. L. (2003). A Life against the Grain. Piscataway: Transaction Publishers.

Stern, N. (2007). The Economics of Climate Change. Oxford: OUP. http://dx.doi.org/10.1017/CBO9780511817434

Wildavsky, A. (1979, 1987). Speaking Truth to Power. Piscataway:Transaction Publishers.

Wildavsky, A. (1997). But Is It ReallyTrue? Cambridge, MA: Harvard U.P.

Williamson, O. (1973). Hierarchies and Markets. New York: Free Press.

\section{Copyright Disclaimer}

Copyright for this article is retained by the author(s), with first publication rights granted to the journal.

This is an open-access article distributed under the terms and conditions of the Creative Commons Attribution license (http://creativecommons.org/licenses/by/3.0/). 